\title{
Kayaçlarda Doku Katsayısı ile Kesilebilirlik Özellikleri Arasındaki Bağıntıların İncelenmesi
}

\author{
Dilara HİÇYILMAZ GÜZEL'1 (D), Kamil YILMAZ² (D) \\ 1,2Süleyman Demirel Üniversitesi, Mühendislik Fakültesi, Jeoloji Mühendisliği Bölümü, 32260, Isparta, Türkiye
}

(Alınış / Received: 05.12.2018, Kabul / Accepted: 12.04.2019, Online Yayınlanma / Published Online: 30.08.2019)

\author{
Anahtar Kelimeler \\ Doku katsayısı, \\ Spesifik enerji, \\ Mineraloji
}

Özet: Kayaçların kesilebilirlik özelliklerini etkileyen en önemli faktör kayaçların dayanımlarıdır. Kayaç dayanımı ise kayacın doku özellikleri ve kayaç oluşturan mineral tanelerinin kayaç içinde bulunma durumuna bağlıdır. Verimi yüksek kesimler yapabilmek adına kesilecek kayaçların mineralojik içeriğinin bilinmesi gerekmektedir. Bu sebeple, doku ve mineral tanelerinin geometrik şekillerinin bir bütün olarak ele alındığı doku katsayısı parametresi (TC) ile birim hacim bașına harcanan enerji miktarı olarak tanımlanan spesifik enerji (SE) arasındaki ilişki araştırılmıştır. Çalışmalarda Afyon ve Isparta bölgelerinden alınan 7 farklı türde toplamda 41 adet numune kullanılmıștır. Numuneler ilgili standartlara bağlı olarak fiziksel ve mekanik deneylere tabi tutulmuştur. Her numunenin mineralojik ve petrografik özellikleri mikroskop altında incelenmiştir. Görüntü analiz programı kullanılarak bilgisayar ortamında mikroskop görüntüleri üzerinden partikül analizi yapılmıştır. Çalışma sonucunda spesifik enerji ile doku katsayısı arasında anlamlı bir ilişki elde edilmiştir. Böylece kayaçların doku özelliklerinin sayısallaştırılması için doku katsayısının kullanılabileceği gözlenmiştir. Buna ek olarak, mineral tanelerin geometrik şekilleri, büyüklükleri, idiomorf veya hipidiyomorf mineraller, kayadaki minerallerin varlığı ve mineraller arasındaki artan sınır ilişkilerinin kayaç mukavemetini ve özgül enerji kullanımını etkilediği gösterilmiştir.

\section{Investigation of the Relationship Between the Texture Coefficient with Rock Cuttability Features}

\section{Keywords}

Texture coefficient, Specific energy, Mineralogy

\begin{abstract}
The most important factor affecting the cuttability properties of rocks is the strength of the rocks. Rock strength depends on the rock characteristics and the presence of rock-forming mineral grains. The mineralogical content of the rocks need to be known in order to make high yields cuttings. For this reason, the relationship between the tissue coefficient parameter, where the geometric shapes of the textures and mineral grains were considered as a whole, and the specific energy defined as the amount of energy spent per unit volume was investigated. A total of 41 samples were collected from seven different species from Afyon and Isparta. The samples were subjected to physical and mechanical experiments depending on the relevant standards. Mineralogical and petrographical properties of each sample were examined under a microscope. Particle analysis was performed by using microscope images in computer environment using image analysis program. As a result of the study, a significant relationship was found between specific energy and tissue coefficient. Thus, it was observed that the coefficient of tissue coefficient can be used for digitizing the textural properties of the rocks. In addition, geometric shapes of mineral grains, size, idiomorph or hypidiomorphic minerals, the presence of minerals in the rock and increased boundary relationships between minerals have been shown to affect rock strength and specific energy use.
\end{abstract}




\section{Giriş}

Maden sektörünün vazgeçilmez unsuru dairesel testereler ile verimli kesimler yapabilmek için kesilecek kayacın dayanımını belirleyen kesilebilirlik önemli bir unsurdur. Verimli kesim; kayacın istenilen boyutlarda mümkün olduğunca az enerji, kısa süre ve kırık-çatlak gibi olumsuz etmenlerin olmamasıyla elde edilir.

Kayaçlarda doku ise kayacı oluşturan kayaç yapıcı mineral taneleri, mikrolitler, varsa damarlar ve tanelerin birbirine bağlanmasını sağlayan matriks malzemesinden oluşur. Mineral tanelerinin birbiriyle olan ilişkileri, aralarındaki mesafe, bu mesafe arasını dolduran matriks, kayacın bileşimindeki mineral yüzdeleri vb. özellikler kayacın dayanımını belirlemektedir. Dayanımın yükselmesi mermercilikte doğaltaşlar üzerinde ebatlama yapabilmek için kullanılan makinalar ile kesim yapılırken kesimin verimsiz olmasına, kesim işleminde kullanılacak olan makinaların zorlanmasına, fazla güç kullanmasına veya bozulmasina neden olur. $\mathrm{Bu}$ da kullanilacak kayaçların istenmeyen şekilde kırılması, çatlaması gibi üretimin verimini düşüren ve zaman kaybına sebep olan büyük bir nedendir. Bu nedenle dayanım kayaçların dayanımları kesimi etkileyen en önemli unsurlardan biridir. $\mathrm{Bu}$ sebeple kayacın dokusal özelliklerinin belirlenmesi ile kayaca ait kesilebilirlik özellikleri arasındaki ilişskinin tanımlanması önemlidir.

Kayaç tane özellikleri ile kesilebilirlik ilişkisini incelemek adına Şengün [1] dairesel testereler kullanarak birçok kayaç kesimi gerçekleştirmiş ve bunların özgül enerjilerini hesaplamıştır. Ayrıca dairesel testerelerle kesme işleminde kayaca bağlı faktörlerde sert mineral tane boyutu, sertlik, dayanım gibi malzeme özellikleri ile numunelerin kesilebilirlik özelliklerini araştırmıştır. Kayaçların sert mineral tane boyutu büyüdükçe, sertlik ve dayanım değerleri arttıkça kesilebilirliklerinin azaldığını vurgulamıştır.

Şengün ve diğerleri [2] bazı doğal taşların kesilebilirliklerini incelemek amacıyla almış oldukları örneklerden ilgili deney standartlarına göre numuneler hazırlayarak kayaçların fiziksel ve mekanik özellikleri ile kesilebilirlik özelliklerini belirlemiştir. Kesim parametrelerini sabit tutarak ölçülen verileri kullanarak her kayaç türü için spesifik enerji hesaplamıștır. Çalışma sonucunda numunelerin fiziksel özelliklerinden gözeneklilik derecesi ve sertliğinin, mekanik özelliklerden ise kayaç basınç dayanımının kayaçların kesilebilirlikleri üzerinde etkisinin olduğunu vurgulamıştır.

Öztürk [3] kayaçların dayanımlarının malzeme özelliklerine bağlı olduğunu ve mineral kompozisyonlarından etkilendiğini buna bağlı olarak da malzemelerin dayanımlarının, kayacı oluşturan minerallere, bu minerallerin bulunduğu dokuya ve dokunun kompozisyonuna bağlı olarak değiştiğini vurgulamıştır. $\mathrm{Bu}$ nedenle agrega numuneleri üzerinde fiziksel ve mekanik deneyleri yaparak doku katsayısı ile ilişkilerini araştırmıştır. Doku katsayısı ile fiziksel-mekanik özellikler arasında bir ilişkinin var olduğunu ve doku katsayısının kullanılabilir bir parametre olduğu sonucuna ulaşmıştır.

Kesilebilirlik özelliklerinin araştırılması yanı sıra kayacı ve kayacı oluşturan minerallerin özelliklerini tanımlamaya ihtiyaç duyulmaktadır.

Farklı kayaç türlerinde kullanılacak enerji değerlerini sayısal olarak belirlemek adına Howarth ve Rowlands [4] tarafindan doku katsayısı parametresini belirlemiştir. Kayaçlara ait minerallerin geometrik özellikleri ve bulundukları kayaca ait dokusal tüm özelliklerinin bir arada incelenerek kayaç dayanımlarının sayısallaştırılmasını sağlayan bu parametre ile kesim esnasında dairesel testerelerin kullanmış olduğu birim hacim için harcanan enerji miktarı olan spesifik enerji arasındaki ilişki araştırılmıştır.

Öztürk ve diğerleri [5] kayaçların doku katsayıları ile fiziko-mekanik özellikleri arasındaki ilişkileri incelemiştir. Kayaçlara ait doku katsayısı değerinin artmasıyla kayaç dayanımının yükseldiğini yani kaya sağlamlığını olumlu yönde etkileyen parametrelerin artışının doku katsayısı değerinin artışına sebep olduğunu ifade etmiştir.

Kumtaşı örnekleri üzerinde mineralojik-petrografik analizler, kaya ve kazı mekaniği deneyleri yapan Tiryaki ve diğerleri [6] doku katsayısı ve paketlenme yoğunluğunun, spesifik enerji ile istatiksel açıdan bir ilişkisinin varlığını vurgulamışlardır.

Günaydın [7] andezit, traki andezit, trakit ve kumtaşı numunelerini kullanarak doku katsayıları tespit etmiștir. Ayrıca bu numunelerin fiziksel ve mekanik özelliklerini inceleyerek doku katsayısı ile ilişkilerinin olup olmadığını araştırmıştır. Doku katsayısının fiziko-mekanik özellikleri etkilediğini ifade etmiştir.

Bu çalışmada doku katsayısı parametresi ile dairesel testerelerin kesim esnasında kullandıkları özgül kesme enerjisi (spesifik enerji) arasındaki ilişkiler araştırılmıştır. Çalışmada amaç kayaçların mineral içerikleri ve dokusal özelliklerinin kesilebilirliklerine ve buna bağlı olarak dairesel testerelerle yapılan kesimlerde verime etkisinin araştırılmasıdır Afyon ve Isparta illerine ait formasyonlar da baskın olarak bulunan 7 farklı kayaç türüne ait toplam 41 numune kullanılarak kayaçların spesifik enerjilerine olumlu ya da olumsuz olarak etki edebilecek fiziksel ve mekanik özellikleri ile dokusal özellikleri deneylerle tespit edilerek ilişkileri araştırılmıştır. Buna bağlı olarak çıkan sonuçlar doğrultusunda kayaçların kesim parametrelerinden olan spesifik enerji üzerinde doku katsayısı değerinin etkileri 
gözlemlenmiş olup, ilişkilere dair tüm veri ve analizlere çalışmada yer verilmiştir.

Bunların yanı sıra her numune için görüntü analiz programında ince kesitlere ait görüntüler kullanılarak partikül analizleri yapılmış ve çıkan değerler yardımıyla doku katsayıları belirlenmiştir. Tüm deney sonuçları ve doku katsayısı değerleriyle kayaçların kesilebilirlik özellikleri ile doku katsayıları arasındaki ilişkiler irdelenmiştir.

\section{Materyal ve Metot}

Çalışma kapsamında Tablo 1'de belirtilen numuneler üzerinde standartlara uygun olarak bazı fiziksel ve mekanik özellikler ile ilgili deneyler yapılmıştır. Ayrıca her numune için ince kesit yapılarak mineralojik ve petrografik tayinler yapılıp, mikroskop altındaki görüntüler üzerinden görüntü analiz programı yardımıyla partikül analizleri yapılmıştır.

Tablo 1. Kullanılan numuneler ve kodları

\begin{tabular}{|c|c|c|c|c|c|}
\hline Grup & Kayaç & Kayaç & Grup & Kayaç & Kayaç \\
\hline Kodu & Kodu & Adl & Kodu & Kodu & Adı \\
\hline \multirow{3}{*}{ IS-1 } & Is-1A & \multirow{3}{*}{ Trakiandezit } & \multirow{4}{*}{ AF-1 } & Af-2 & \\
\hline & Is-1B & & & Af-5 & \\
\hline & Is-1C & & & Af-10 & \\
\hline \multirow{4}{*}{ IS-2 } & Is-2A & \multirow[b]{4}{*}{ Kumtaşı } & & Af-12 & Lösitit \\
\hline & Is-2B & & \multirow[t]{2}{*}{ AF-2 } & Af-13 & Andezitik \\
\hline & Is- $2 \mathrm{C}$ & & & Af-14 & Bazalt \\
\hline & Is-2D & & \multirow{7}{*}{ AF-3 } & Af-4 & \\
\hline \multirow{10}{*}{ IS-3 } & Is-3A & \multirow[b]{10}{*}{ Trakit } & & Af-6 & \\
\hline & Is-3B & & & A-7 & \\
\hline & Is-3C & & & Af-8 & \\
\hline & Is-3D & & & Af-9 & \\
\hline & Is-4A & & & Af-11 & Bazaltik \\
\hline & Is- $4 B$ & & & Af-15 & Trakiandezit \\
\hline & Is-6A & & \multirow{3}{*}{ AF-4 } & Af-3 & \\
\hline & Is-6B & & & Af-16 & Trakiandezit \\
\hline & Is-6C & & & Af-17 & \\
\hline & Is-6D & & & & \\
\hline \multirow{4}{*}{ IS-4 } & Is-4C & & & & \\
\hline & Is-5A & & & & \\
\hline & Is-5B & Bazaltik & & & \\
\hline & Is-5C & Trakiandezit & & & \\
\hline \multirow{4}{*}{ IS-5 } & Is-7 A & & & & \\
\hline & Is-7 B & & & & \\
\hline & Is-7C & & & & \\
\hline & Is-7D & Fonolit & & & \\
\hline
\end{tabular}

\subsection{Mineralojik ve petrografik özelliklerin belirlenmesi}

Petrografik özellikleri belirlenen numunelere ait ince kesitler polarizan mikroskop yardımıyla incelenerek kayaç adlandırılmaları (Tablo 1) ve mineralojik içerikleri irdelenmiştir (Tablo 2,3).

\subsection{Numunelerin doku katsayısı değerlerinin belirlenmesi}

Kayaçların dayanımlarının kesime etkisini öngörebilmek amacıyla kayaç içerisindeki mineral tanelerinin geometrik özellikleri ve içerisinde bulunduğu kayacın dokusal özelliklerini sayısallaştırılmış şekilde bir arada inceleyebilmek amacıyla doku katsayısı hesabı yapılmıştır. Doku katsayısı için gereken değerler; mineral tanesine ait geometrik özellikler; tanenin uzunluğu (maksimum feret çapı), tanenin genişliği (minimum feret çapı), tanenin çevresi, tanenin açısı (tane oryantasyonu) ve hesaplama yapmak için seçilen sınır içerisindeki matriks malzemesinin alanıdır. Her bir numuneye ait ince kesitin mikroskop altındaki görüntüsü android telefonla fotoğraflar büyütme yapılmadan (1X) çekildi ve bilgisayar ortamına aktarıldı. Her numuneye ait doku katsayısı değerini bulabilmek adına minerallerin gerekli geometrik parametreleri hesaplandı. Bu değerleri elde edebilmek için ImageJ adlı sürüm 2.1.4.7 görüntü analizi programında tamamen otomatik olarak, ölçekli fotoğraflar üzerinden partikül analizi yapıldı.

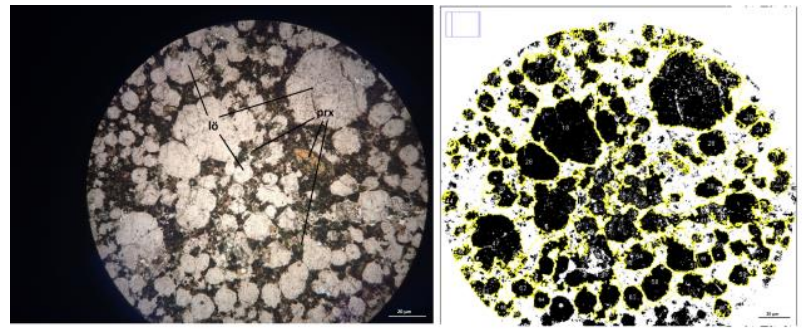

Şekil 1. Af-12 Lösitit numunesine ait mikroskop ve partikül analizi yapılmış görüntüsü

Analiz sonuçları program tarafından otomatik olarak Excel dosyasına kaydedildi.

$$
T C=A W\left[\left(\frac{N_{0}}{N_{0}+N_{1}} \times \frac{1}{F F_{0}}\right)+\left(\frac{N_{1}}{N_{0}+N_{1}} \times A R_{1} \times A F_{1}\right)\right]
$$

Eşitlik (1) ile hesaplanan doku katsayısına ait parametreler [2] burada;

AW, Tane yı̆̆ılma ağırlığı,

$\mathrm{N}_{o}$,Görünüm oranı (AR) 2,0' dan küçük olan tane sayısı,

$\mathrm{N}_{1}$, AR değeri 2.0' dan büyük olan tane sayısı,

$\mathrm{FF}_{0}$, AR değeri 2.0' dan küçük olan tanelerin şekil faktörü (FF) değerlerinin aritmetik ortalaması,

$\mathrm{AR}_{1}, \mathrm{AR}$ değeri 2.0' dan büyük olan tanelerin $\mathrm{AR}$ değerlerinin aritmetik ortalaması,

$\mathrm{AF}_{1}$, Açı faktörünü ifade etmektedir.

AR parametresi ile sapmayı gözlemlemek mümkün olmaktadır. AR değeri, tanenin uzunluğunun genişliğine oranı olarak tanımlanmaktadır. AR değerinin 2.0 olduğu durum sınır olarak kabul edilmesiyle (Howarth ve Rowlands, 1987) sapmiş ve sapmamış taneler ayırt edilir. FF değeri ise tanenin yuvarlaklıktan ne derece sapmiş olduğunu tanımlamaya yarayan bir parametredir. Bu sayede FF değeri kullanılarak, tanenin ne derece pürüzlü olduğu hakkında yorum yapmak mümkün olmaktadır. FF değeri Eşitlik (2) yardımıyla hesaplanmaktadır.

$$
F F=4 \times \pi \times \frac{\text { Alan }}{(\text { Çevre })^{2}}
$$


AF; açı faktörü sapmış tanelerin yatay eksenle yapmış olduğu dar açıdır. Hesabı Eşitlik 3 yardımıyla yapılır.

$$
Q_{L}=\sum_{i=1}^{n}\left(\frac{x_{i}}{\frac{N_{1}\left(N_{1}-1\right)}{2}}\right) x_{i}
$$

Burada; $\mathrm{N}_{1}$, sapmış $(\mathrm{AR}<2.0)$ tane sayısı, i, ağırlık katsayısı ve $\mathrm{x}_{\mathrm{i}}$, iki açı arasındaki farkın mutlak değerinin dar açı cinsinden değeridir.

Parametrelerin sonuncusu olan AW yani yı̆̆ılma ağırlığı değeri Eşitlik (4) yardımıyla bulunur.

$$
A W=\frac{\text { Toplam tane alanı }}{\text { Referans alanı }}
$$

Son olarak tüm bu parametreler yardımıyla her bir numuneye ait doku katsayısı Eşitlik (1) ile hesaplanır.

\subsection{Fiziksel ve mekanik özelliklerin belirlenmesi}

Alınan numuneler Süleyman Demirel Üniversitesi Maden Mühendisliği Bölümü Doğal Taşlar Teknolojisi Laboratuvarın da TSE ve ISRM'ye göre belirlenen fiziksel özelliklerinin elde edilebilmesi için yapılan deneylerle numunelerin birim hacim ağırlığı (TS EN 1936) [8], görünür porozitesi (TS EN 13755)[9], kütlece su emme oranı (TS EN 13755)[9], sismik hız (TS EN 14579)[10], Schmidt sertliği (ISRM 1981)[11] gibi, mekanik özellik olarak ise nokta yükü dayanım indeksi (ISRM 1981)[11] özellikleri belirlenmiştir.

\subsection{Numunelerin spesifik enerjilerinin belirlenmesi}

Numuneler yapılan diğer deneylere ait standart deney boyutlardan farklı olarak 5-10-20 cm boyutlarında kullanılmıştır. Dairesel testereyle, bilgisayara bağlı bir düzenek kullanılarak (Șekil 1), ilerleme hızı, çevresel hız, testere çapı, kesme derinliği ve kesim süresi sabit tutularak numunelerin kesimleri esnasında kullanılan güç ve süre değerleri ölçülmüştür.

Her numune üzerinde 3 kez tekrarlanan işlem için güç-süre grafiği hazırlanarak bulunan değerlerin ortalaması hesaplanmıştır.

Burada güç; kayacın kesimi esnasında dairesel testerenin keski ucunun tamamıla kayaca temas ederek aşındırmaya başladığı andan itibaren makinenin harcamış olduğu güç, süre ise keski ucunun tamamen kayaca temasının bașladı̆̆ ve bittiği zaman arasındaki süredir (Șekil 2). Dairesel testerenin bağlanmış olduğu bilgisayar üzerinden tüm numunelerin kayaç kesimlerine ait gerilim (V), frekans ve akım (I) değerleri salt metin dosyaları halinde alınmıştır. Daha sonra Microsoft Excel programı formatına dönüștürülen değerler bir deney için anlık olarak kaydedilen akım ve gerilim değerleri çarpılarak kesim esasında oluşan anlık güç değerleri hesaplanmıştır [4].

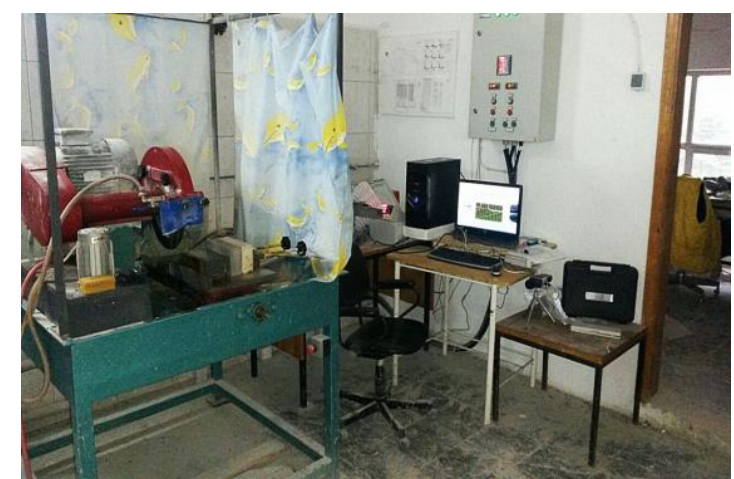

Şekil 2. Deneyin yapılmış olduğu düzenek

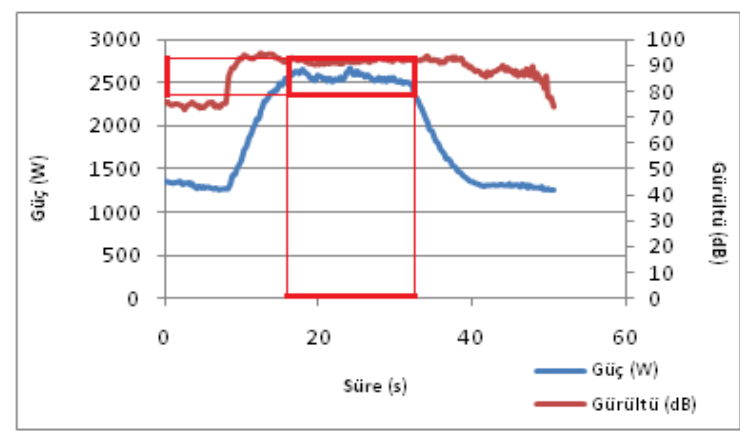

Şekil 3. Is-2D numunesi 1.kesimi için güç-süre grafiği

Bulunan değerler yardımıyla her numuneye ait spesifik enerji değerleri Eşitlik (5) ve Eşitlik (6) ile hesaplanmıștır.

$$
\mathrm{P}=\mathrm{V} \times \mathrm{I}
$$

Burada;

$\mathrm{P}$, anlık çekilen güç (watt),

$\mathrm{V}$, anlık gerilim değeri (volt),

I, anlık akım değerini (amper) ifade etmektedir.

$$
\mathrm{P}_{\text {net }}=\mathrm{P}_{\mathrm{k}}-\mathrm{P}_{\mathrm{b}}
$$

Burada;

Pnet, kesim için harcanan net güç değeri (watt), $\mathrm{Pk}$, testere tam kesimde iken çekilen güç değeri (watt),

$\mathrm{Pb}$, testere boşta iken çekilen güç değerini (watt) ifade eder.

\section{Bulgular}

\subsection{Mineralojik ve petrografik bulgular}

Tüm mineralojik ve petrografik incelemeler sonucunda Afyon ve Isparta olarak ayrılan kayaçlar adlandırma kodları ve mineralojik özellikleriyle tablolar halinde verilmiştir (Tablo 2,3).

\subsection{Numunelerin doku katsayısı değerleri}

Numunelere ait doku katsayısı değerleri belirlenirken ilgili parametreler hesaplanmıștır. Her numune için ayrı ayrı hesaplanan doku katsayısı hesap tablosu Tablo 4 de, tüm numuneler için hesaplanmış olan parametre değerleri Tablo 5 de verilmiştir. 
Tablo 2. Isparta numuneleri mineralojik tablosu

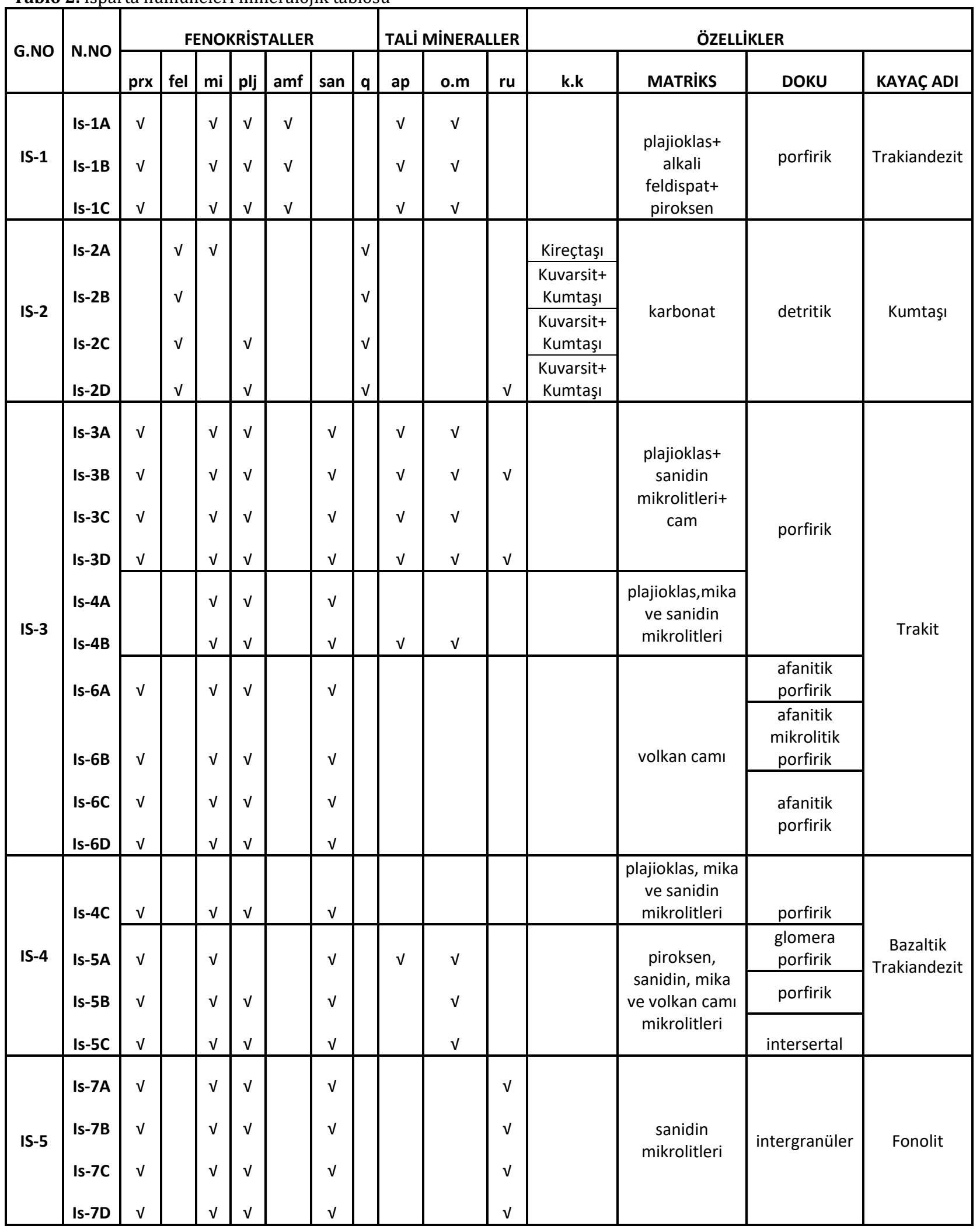

(prx: Piroksen, fel: Feldispat, mi: Mika, plj: Plajiyoklas, amf: Amfibol, san: Sanidin, q: Kuvars, ap: Apatit, o.m: Opak Mineral, ru: Rutil, k.k: Kayaç Kırıntısı) 
Tablo 3. Afyon numuneleri mineralojik tablosu

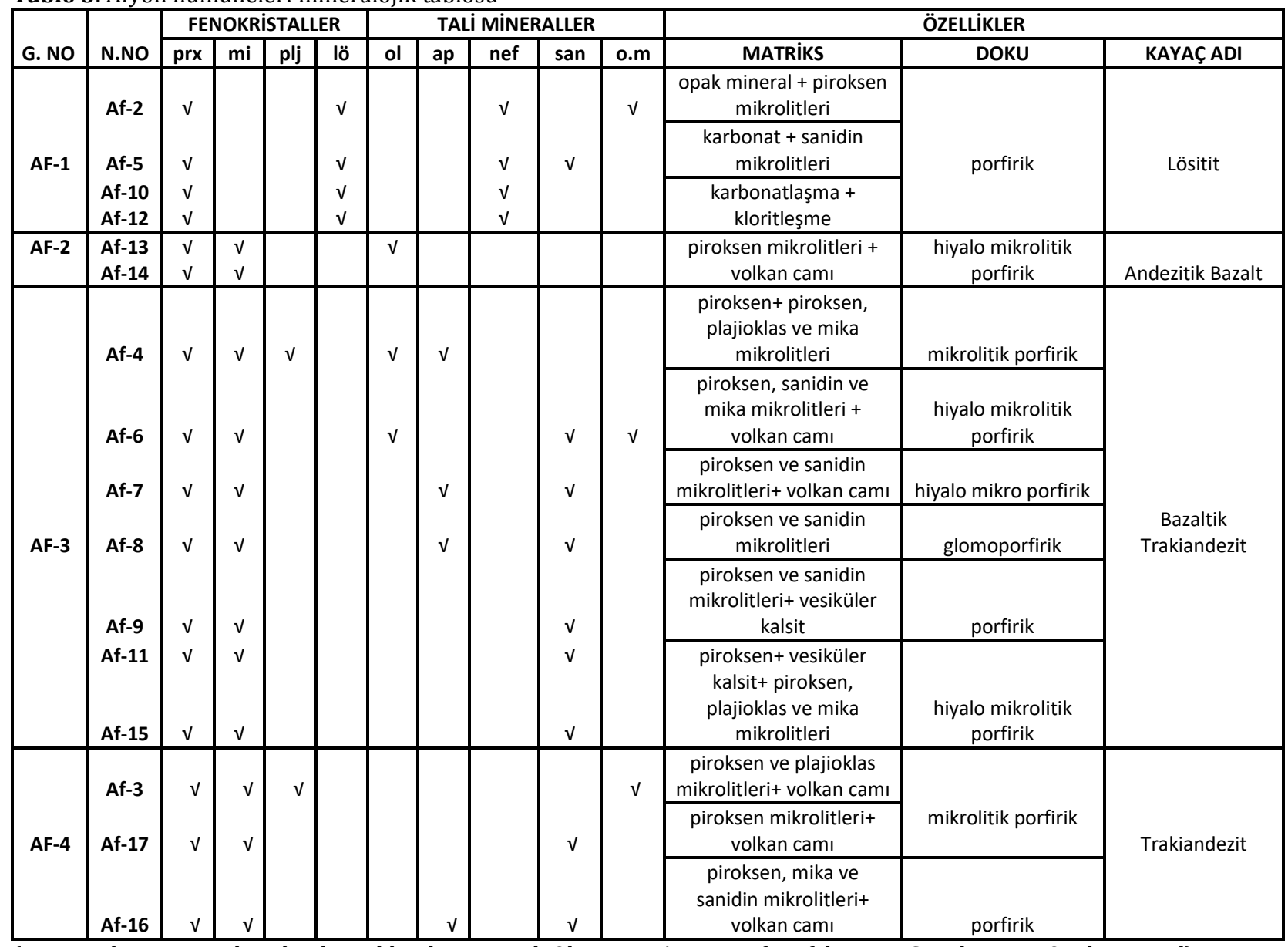

(prx: Piroksen, mi: Mika, plj: Plajiyoklas, lö: Lösit, ol: Olivin, ap: Apatit, nef: Nefelin, san: Sanidin, o.m: Opak Mineral)

Tablo 4. Is-1A numunesine ait doku katsayısı parametrelerine ait değerler

\begin{tabular}{|c|c|c|c|c|c|c|c|c|c|c|c|c|c|c|c|c|}
\hline Tane No & Alan & Çevre & Max. Feret & Min. Feret & Açı $\left({ }^{\circ}\right)$ & AR & FF & AW & $\mathrm{FF}_{0}$ & $A R_{1}$ & $\frac{N(N-1)}{2}$ & $\mathbf{i}$ & $1 / N$ & $\mathrm{i} / \mathbf{N}$ & $\mathrm{AF}_{1}$ & TC \\
\hline 1 & 623 & 308.58 & 46.95 & 16.90 & 78.25 & 2.78 & 0.08 & 0.79 & 0.17 & 2.69 & 21 & 8 & 0.14 & 1.14 & 1.09 & 4.04 \\
\hline 6 & 1502 & 578.91 & 72.14 & 26.51 & 54.22 & 2.72 & 0.06 & 0.79 & 0.17 & 2.69 & 21 & 6 & 0.14 & 0.86 & 1.09 & 4.04 \\
\hline 9 & 93342 & 3077.6 & 522.18 & 227.6 & 1.226 & 2.29 & 0.12 & 0.79 & 0.17 & 2.69 & 21 & 1 & 0.14 & 0.14 & 1.09 & 4.04 \\
\hline 12 & 2561 & 1003.1 & 90.64 & 35.98 & 89.91 & 2.52 & 0.03 & 0.79 & 0.17 & 2.69 & 21 & 9 & 0.14 & 1.29 & 1.09 & 4.04 \\
\hline 14 & 671 & 181.87 & 49.83 & 17.14 & 119.6 & 2.91 & 0.25 & 0.79 & 0.17 & 2.69 & 21 & 3 & 0.14 & 0.43 & 1.09 & 4.04 \\
\hline 20 & 4250 & 677.28 & 129.08 & 41.92 & 173.9 & 3.08 & 0.12 & 0.79 & 0.17 & 2.69 & 21 & 9 & 0.14 & 1.29 & 1.09 & 4.04 \\
\hline 41 & 524 & 223.52 & 40.89 & 16.32 & 101.9 & 2.51 & 0.13 & 0.79 & 0.17 & 2.69 & 21 & 2 & 0.14 & 0.29 & 1.09 & 4.04 \\
\hline 3 & 1033 & 316.52 & 46.10 & 28.53 & 44.8 & 1.62 & 0.13 & 0.79 & 0.17 & 2.69 & & & & & & 3.99 \\
\hline 4 & 3362 & 1235.7 & 80.55 & 53.15 & 179.5 & 1.52 & 0.03 & 0.79 & 0.17 & 2.69 & & & & & & 3.99 \\
\hline 7 & 1144 & 211.08 & 51.24 & 28.43 & 66.9 & 1.80 & 0.32 & 0.79 & 0.17 & 2.69 & & & & & & 3.99 \\
\hline 13 & 1506 & 375.14 & 59.51 & 32.22 & 95.56 & 1.85 & 0.13 & 0.79 & 0.17 & 2.69 & & & & & & 3.99 \\
\hline 16 & 1699 & 206.84 & 54.42 & 39.75 & 8.655 & 1.37 & 0.50 & 0.79 & 0.17 & 2.69 & & & & & & 3.99 \\
\hline 17 & 2332 & 449.33 & 73.93 & 40.16 & 68.45 & 1.84 & 0.15 & 0.79 & 0.17 & 2.69 & & & & & & 3.99 \\
\hline 21 & 1092 & 462.26 & 49.01 & 28.37 & 88.57 & 1.73 & 0.06 & 0.79 & 0.17 & 2.69 & & & & & & 3.99 \\
\hline 24 & 2644 & 1004.3 & 71.90 & 46.82 & 37.66 & 1.54 & 0.03 & 0.79 & 0.17 & 2.69 & & & & & & 3.99 \\
\hline 25 & 8084 & 547.45 & 131.04 & 78.55 & 139.8 & 1.67 & 0.34 & 0.79 & 0.17 & 2.69 & & & & & & 3.99 \\
\hline 27 & 1527 & 748.53 & 51.85 & 37.50 & 177 & 1.38 & 0.03 & 0.79 & 0.17 & 2.69 & & & & & & 3.99 \\
\hline 28 & 8370 & 713.56 & 120.94 & 88.12 & 174 & 1.37 & 0.21 & 0.79 & 0.17 & 2.69 & & & & & & 3.99 \\
\hline 29 & 630 & 285.02 & 35.36 & 22.69 & 158.4 & 1.56 & 0.10 & 0.79 & 0.17 & 2.69 & & & & & & 3.99 \\
\hline 31 & 679 & 244.29 & 37.15 & 23.27 & 68.03 & 1.60 & 0.14 & 0.79 & 0.17 & 2.69 & & & & & & 3.99 \\
\hline 32 & 548 & 240.64 & 31.97 & 21.82 & 165 & 1.47 & 0.12 & 0.79 & 0.17 & 2.69 & & & & & & 3.99 \\
\hline 33 & 9858 & 676.16 & 142.06 & 88.35 & 106.7 & 1.61 & 0.27 & 0.79 & 0.17 & 2.69 & & & & & & 3.99 \\
\hline 36 & 28560 & 1013.8 & 213.17 & 170.6 & 125.6 & 1.25 & 0.35 & 0.79 & 0.17 & 2.69 & & & & & & 3.99 \\
\hline 38 & 5392 & 1362.5 & 92.77 & 74.00 & 155 & 1.25 & 0.04 & 0.79 & 0.17 & 2.69 & & & & & & 3.99 \\
\hline 39 & 1069 & 544.68 & 44.37 & 30.67 & 102.5 & 1.45 & 0.05 & 0.79 & 0.17 & 2.69 & & & & & & 3.99 \\
\hline T.Alan & 183002 & & & & & & & & & & & & & Is-1A & $\mathrm{TC}$ & 4.02 \\
\hline R. Alan & 232718 & & & & & & & & & & & & & & & \\
\hline $\mathbf{N}_{0}$ & 18 & & & & & & & & & & & & & & & \\
\hline $\mathbf{N}_{1}$ & 7 & & & & & & & & & & & & & & & \\
\hline
\end{tabular}


Tablo 5. Numunelere ait doku katsayısı parametreleri sonuçları

\begin{tabular}{|l|l|l|l|l|l|l|}
\hline \multicolumn{1}{|c|}{ N.Kodu } & AW & \multicolumn{1}{c|}{ No } & \multicolumn{1}{c|}{ N1 } & \multicolumn{1}{c|}{ AF1 } & \multicolumn{1}{c|}{ FFO } & \multicolumn{1}{c|}{ AR1 } \\
\hline Is-1A & 0.79 & 18 & 7 & 1.09 & 0.17 & 2.69 \\
\hline Is-1B & 0.88 & 15 & 10 & 0.88 & 0.17 & 2.99 \\
\hline Is-1C & 0.72 & 14 & 11 & 1.18 & 0.11 & 3 \\
\hline Is-2A & 0.4 & 13 & 12 & 1.15 & 0.38 & 2.34 \\
\hline Is-2B & 0.88 & 21 & 6 & 1.1 & 0.19 & 2.8 \\
\hline Is-2C & 0.73 & 12 & 13 & 1.23 & 0.36 & 2.56 \\
\hline Is-2D & 0.64 & 20 & 5 & 0.76 & 0.09 & 2.92 \\
\hline Is-3A & 0.62 & 15 & 10 & 0.8 & 0.41 & 2.59 \\
\hline Is-3B & 0.92 & 15 & 10 & 0.98 & 0.12 & 2.44 \\
\hline Is-3C & 0.72 & 14 & 11 & 0.68 & 0.08 & 3.18 \\
\hline Is-3D & 0.69 & 19 & 6 & 0.97 & 0.11 & 2.71 \\
\hline Is-4A & 0.62 & 15 & 10 & 0.88 & 0.07 & 2.4 \\
\hline Is-4B & 0.74 & 19 & 6 & 1.07 & 0.1 & 2.76 \\
\hline Is-4C & 0.53 & 15 & 10 & 0.66 & 0.09 & 2.61 \\
\hline Is-5A & 0.45 & 15 & 10 & 1.04 & 0.13 & 2.52 \\
\hline Is-5B & 0.57 & 19 & 6 & 1.1 & 0.12 & 2.21 \\
\hline Is-5C & 0.35 & 11 & 14 & 1.07 & 0.22 & 2.65 \\
\hline Is-6A & 0.98 & 21 & 4 & 0.95 & 0.22 & 2.28 \\
\hline Is-6B & 0.41 & 21 & 4 & 0.8 & 0.15 & 2.22 \\
\hline Is-6C & 0.3 & 13 & 12 & 0.83 & 0.09 & 2.82 \\
\hline Is-6D & 0.53 & 13 & 12 & 0.85 & 0.2 & 3.04 \\
\hline & & & & & & \\
\hline
\end{tabular}

\begin{tabular}{|l|l|l|l|l|l|l|}
\hline \multicolumn{1}{|c|}{ N.Kodu } & \multicolumn{1}{c|}{ AW } & \multicolumn{1}{c|}{ No } & \multicolumn{1}{c|}{ N1 } & \multicolumn{1}{c|}{ AF1 } & \multicolumn{1}{c|}{ FFO } & \multicolumn{1}{c|}{ AR1 } \\
\hline Is-7A & 0.8 & 10 & 15 & 1.07 & 0.12 & 3.6 \\
\hline Is-7B & 0.8 & 14 & 11 & 0.93 & 0.07 & 2.27 \\
\hline Is-7C & 0.6 & 17 & 8 & 1.03 & 0.34 & 2.63 \\
\hline Is-7D & 0.6 & 15 & 10 & 0.88 & 0.17 & 2.99 \\
\hline Af-2 & 0.5 & 17 & 8 & 1.13 & 0.32 & 2.7 \\
\hline Af-3 & 0.7 & 18 & 7 & 1 & 0.09 & 2.49 \\
\hline Af-4 & 0.4 & 13 & 12 & 0.8 & 0.34 & 3.52 \\
\hline Af-5 & 0.6 & 20 & 5 & 1.16 & 0.29 & 2.66 \\
\hline Af-6 & 0.6 & 15 & 10 & 1.22 & 0.14 & 2.96 \\
\hline Af-7 & 0.5 & 16 & 9 & 0.89 & 0.17 & 2.97 \\
\hline Af-8 & 0.7 & 10 & 15 & 0.91 & 0.09 & 2.77 \\
\hline Af-9 & 0.6 & 14 & 11 & 1.04 & 0.23 & 3.43 \\
\hline Af-10 & 0.3 & 20 & 5 & 0.84 & 0.24 & 3.16 \\
\hline Af-11 & 0.5 & 14 & 11 & 1.04 & 0.09 & 2.89 \\
\hline Af-12 & 0.9 & 21 & 4 & 0.8 & 0.2 & 2.35 \\
\hline Af-13 & 0.4 & 14 & 11 & 0.82 & 0.1 & 2.53 \\
\hline Af-14 & 0.8 & 12 & 13 & 1.05 & 0.07 & 2.52 \\
\hline Af-15 & 0.3 & 14 & 11 & 1.29 & 0.07 & 3.05 \\
\hline Af-16 & 0.7 & 13 & 12 & 1.08 & 0.07 & 2.74 \\
\hline Af-17 & 0.5 & 18 & 7 & 1.06 & 0.14 & 2.57 \\
\hline
\end{tabular}

Numunelere ait deney sonuçlarının ortalama ve standart sapma değerlerini incelendiğinde en yüksek doku katsayısı AF-4 kodlu trakiandezit kayaçlarının oluşturduğu grupta, en düşük doku katsayısı değerleri ise AF-1 kodlu lösitit kayaçlarının oluşturduğu grupta gözlenmiştir (Tablo 6).

Tablo 6. Numunelere ait doku katsayısı değerleri

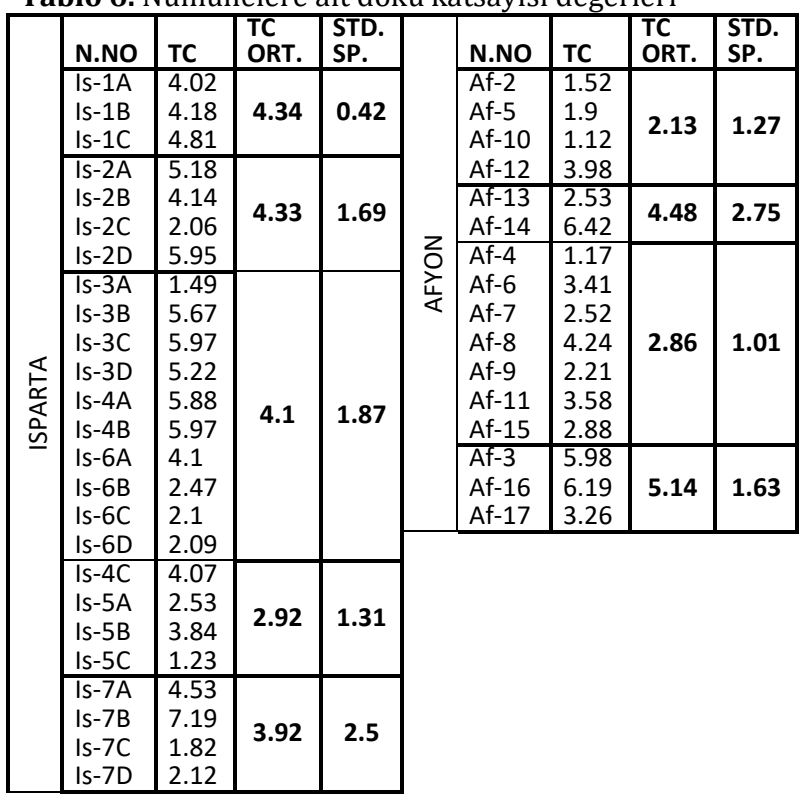

\subsection{Numunelerin fiziksel ve mekanik özellikleri}

En yüksek birim hacim ağırlı (BHA) değeri kumtaşlarından oluşan IS-2 grubunda gözlenmiştir (Tablo 7). En düşük değer ise IS-3 kodlu trakit numunelerine ait grupta gözlenmiştir (Tablo 7).

Sismik Hız (Vp) deneyi en yüksek değer AF-1 kodlu lösititler oluşan grupta, en düşük değer ise IS-3 kodlu trakitlerden oluşan grupta gözlenmiştir (Tablo 8).

Tablo 7. Numunelere ait birim hacim ağırlık değerleri

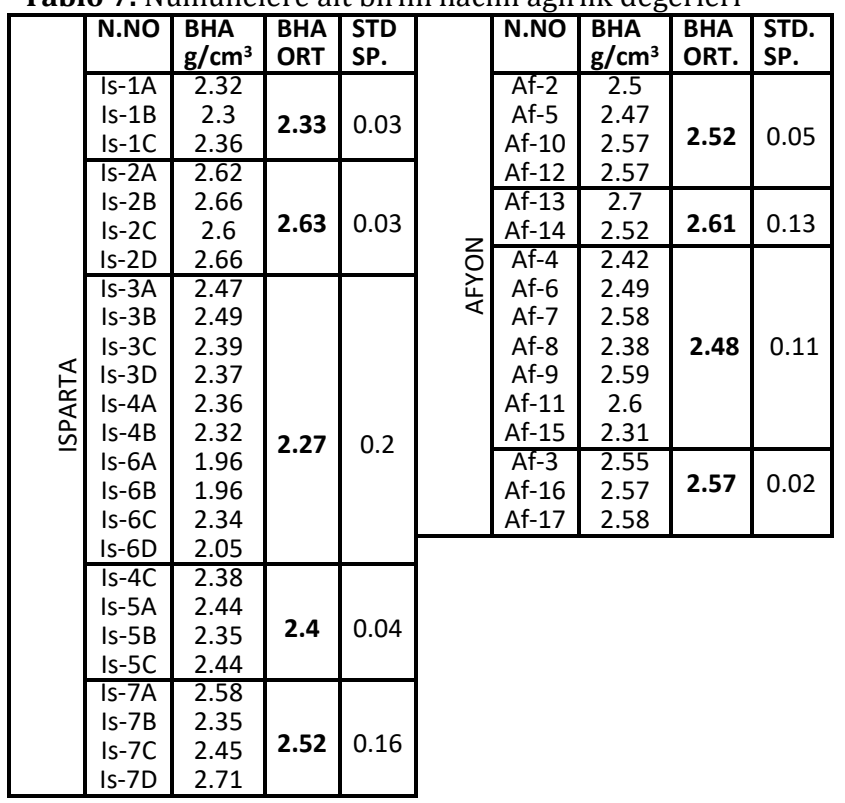

Tablo 8. Numunelere sismik hız değerleri

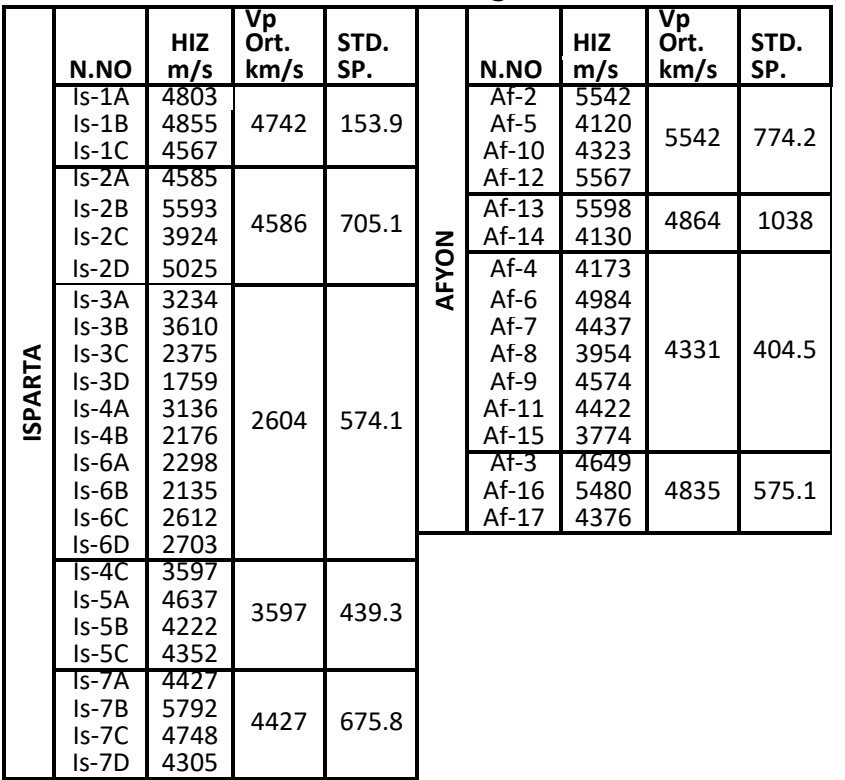


En yüksek Schmidt çekiç sertliği değeri standart sapmaları farklı ancak Schmidt çekiç sertliği değerleri aynı olan IS-4 kodlu bazaltik trakiandezit grubu ve IS5 kodlu fonolit grubudur. En düşük değer ise IS-3 kodlu trakit numunelerinin oluşturduğu grupta gözlenmiştir (Tablo 9).

Tablo 9. Numunelere ait Schmidt çekiç sertliği değerleri

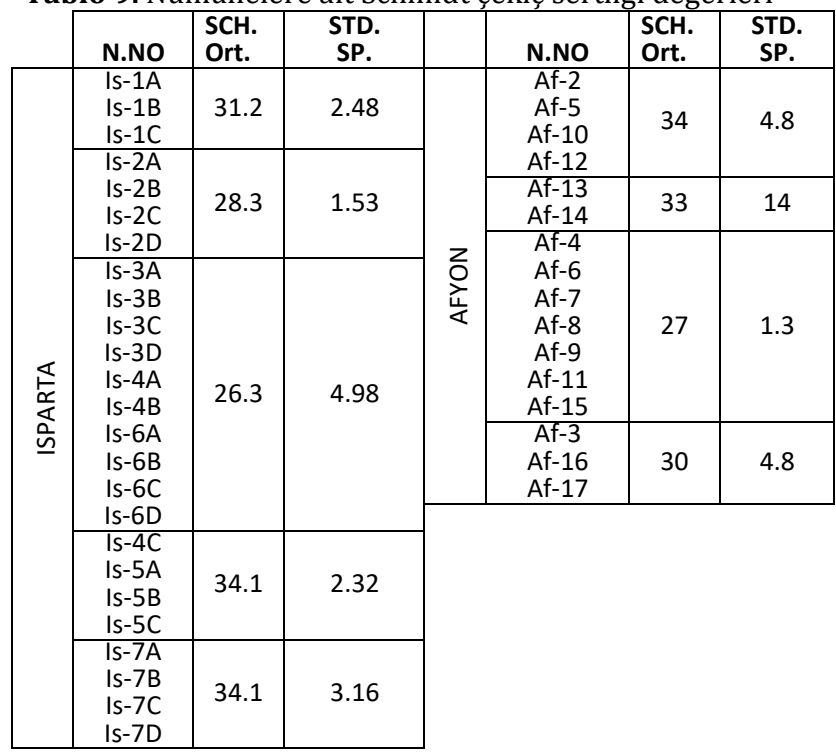

Kütlece su emme (KSE) deneyi değerlerine bakıldığında en yüksek değer IS-3 kodlu trakit numunelerinin oluşturduğu grupta gözlenmiştir. Ancak standart sapma değeri yüksek olduğu için kütlece su emme yüzdesi en yüksek IS-1 grubu trakiandezitler olarak belirlenmiștir. En düșük değer ise kumtaşlarından oluşan IS-2 kodlu grupta gözlenmiştir (Tablo 10).

Tablo 10. Numunelere ait kütlece su emme değerleri

\begin{tabular}{|c|c|c|c|c|c|c|c|c|c|}
\hline & N.NO & ORT. & $\begin{array}{l}\text { KSE } \\
\text { ORT. } \\
\%\end{array}$ & $\begin{array}{l}\text { STD } \\
\text { SP. }\end{array}$ & & N.NO & ORT. & $\begin{array}{l}\text { KSE } \\
\text { ORT. } \\
\%\end{array}$ & $\begin{array}{l}\text { STD } \\
\text { SP. }\end{array}$ \\
\hline & Is-1A & 2.82 & & & & Af-2 & 0.57 & & \\
\hline & $\begin{array}{l}\text { Is-1B } \\
\text { Is-1C }\end{array}$ & $\begin{array}{l}3.05 \\
2.7\end{array}$ & 2.86 & 0.18 & & $\begin{array}{l}\text { Af-5 } \\
\text { Af-10 }\end{array}$ & $\begin{array}{l}3.08 \\
2.96\end{array}$ & 1.74 & 1.49 \\
\hline & Is-2A & 1.01 & & & & Af-12 & 0.33 & & \\
\hline & $\begin{array}{l}\text { Is-2B } \\
\text { Is-2C }\end{array}$ & $\begin{array}{l}0.54 \\
1.19\end{array}$ & 0.91 & 0.28 & & $\begin{array}{l}\text { Af-13 } \\
\text { Af-14 }\end{array}$ & $\begin{array}{l}0.47 \\
2.08\end{array}$ & 1.27 & 1.14 \\
\hline & Is-2D & 0.89 & & & & Af-4 & 3.23 & & \\
\hline & Is-3A & 2 & & & ○ & Af-6 & 1.94 & & \\
\hline & Is-3B & 1.65 & & & 立 & Af-7 & 2.28 & & \\
\hline & Is-3C & $\begin{array}{l}3.39 \\
3.88\end{array}$ & & & & Af-8 & $\begin{array}{l}3.43 \\
1.95\end{array}$ & 2.6 & 0.72 \\
\hline & $\begin{array}{l}\text { IS-3D } \\
\text { Is-4A }\end{array}$ & $\begin{array}{l}3.88 \\
2.71\end{array}$ & & & & $\begin{array}{l}\text { Af-9 } \\
\text { Af-11 }\end{array}$ & $\begin{array}{l}1.95 \\
1.99\end{array}$ & & \\
\hline$\frac{a}{\alpha}$ & Is-4B & 3.53 & 5.56 & 4.25 & & Af-15 & 3.41 & & \\
\hline & $\begin{array}{l}\text { Is-6A } \\
\text { Is-6B }\end{array}$ & $\begin{array}{l}12.29 \\
12.6\end{array}$ & & & & $\begin{array}{l}\text { Af-3 } \\
\text { Af-16 }\end{array}$ & $\begin{array}{l}1.72 \\
0.63\end{array}$ & 1.49 & 0.77 \\
\hline & Is-6C & 3.82 & & & & Af-17 & 2.12 & & \\
\hline & $\frac{\mid \mathrm{Is-6D}}{\mid \mathrm{Is-4C}}$ & $\frac{9.73}{2.48}$ & & & & & & & \\
\hline & $\begin{array}{l}\text { Is-5A } \\
\text { Is-5B }\end{array}$ & $\begin{array}{l}1.97 \\
2.81\end{array}$ & 2.27 & 0.46 & & & & & \\
\hline & Is-5C & 1.81 & & & & & & & \\
\hline & Is-7A & 1.26 & & & & & & & \\
\hline & $\begin{array}{l}\text { Is-7B } \\
\text { Is-7C }\end{array}$ & $\begin{array}{l}1.19 \\
0.81\end{array}$ & 1.16 & 0.25 & & & & & \\
\hline & Is-7D & 1.38 & & & & & & & \\
\hline
\end{tabular}

Numunelere ait görünür porozite (GP) değerlerine bakıldığında en yüksek değer IS-3 kodlu trakit numunelerinin olușturduğu grupta gözlenmiștir. Ancak standart sapma değeri yüksek olduğu için görünür porozite değeri en yüksek IS-1 grubu trakiandezitler olarak belirlenmiştir. En düşük değer IS-2 kodlu kumtaşlarının oluşturduğu grupta gözlenmiştir (Tablo 11).

Tablo 11. Numunelere ait görünür porozite değerleri

\begin{tabular}{|c|c|c|c|c|c|c|c|c|c|}
\hline & N.NO & ORT & $\begin{array}{c}\text { GP } \\
\text { ORT. } \\
\%\end{array}$ & $\begin{array}{l}\text { STD } \\
\text { SP. }\end{array}$ & & N.NO & ORT & $\begin{array}{c}\text { GP } \\
\text { ORT. } \\
\%\end{array}$ & $\begin{array}{l}\text { STD } \\
\text { SP. }\end{array}$ \\
\hline & Is-1A & 6.55 & & & & Af-2 & 1.48 & & \\
\hline & Is-1B & 6.98 & 6.63 & 0.31 & & Af-5 & 7.22 & 421 & 35 \\
\hline & Is-1C & 6.37 & & & & Af-10 & 7.26 & 4.21 & 3.5 \\
\hline & Is-2A & 2.64 & & & & Af-12 & 0.89 & & \\
\hline & Is-2B & 1.42 & & & & Af-13 & 1.26 & & \\
\hline & Is-2C & 3.1 & 2.38 & 0.71 & & Af-14 & 5.24 & 3.25 & 2.81 \\
\hline & Is-2D & 2.37 & & & & Af-4 & 7.82 & & \\
\hline & Is-3A & 4.93 & & & z & Af-6 & 4.79 & & \\
\hline & Is-3B & 4.1 & & & 嵅 & Af-7 & 5.86 & & \\
\hline & Is-3C & 8.1 & & & & Af-8 & 8.15 & 6.39 & 1.5 \\
\hline & Is-3D & 9.21 & & & & Af-9 & 5.06 & & \\
\hline 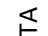 & Is-4A & 6.39 & 1106 & & & Af-11 & 5.15 & & \\
\hline$\frac{\alpha}{<}$ & Is-4B & 8.19 & 11.86 & 7.9 & & Af-15 & 7.85 & & \\
\hline$\underline{\underline{v}}$ & Is-6A & 24.11 & & & & Af-3 & 4.4 & & \\
\hline & Is-6B & 24.68 & & & & Af-16 & 1.62 & 3.83 & 2 \\
\hline & Is-6C & 8.92 & & & & Af-17 & 5.49 & & \\
\hline & Is-6D & 19.97 & & & & & & & \\
\hline & Is-4C & 5.89 & & & & & & & \\
\hline & Is-5A & 4.81 & 5 & 101 & & & & & \\
\hline & Is-5B & 6.61 & & & & & & & \\
\hline & Is-5C & 4.41 & & & & & & & \\
\hline & Is-7A & 3.15 & & & & & & & \\
\hline & Is-7B & 2.97 & 201 & 0,5 & & & & & \\
\hline & Is-7C & 2 & 2.91 & 0.65 & & & & & \\
\hline & Is-7D & 3.53 & & & & & & & \\
\hline
\end{tabular}

Nokta yükü dayanım indeksi (NYD) sonuçlarına ait değerler ortalaması ve standart sapma değerleri ele alındığında en yüksek nokta yükü dayanım indeksi değeri AF-2 kodlu lösitit kayaçlarından oluşan grupta, en düşük değer ise IS-3 kodlu trakit kayaçlarının oluşturduğu grupta gözlenmiştir. Deneylere ait sonuçlar ortalaması Tablo 5'de ve standart sapma değerlerleri Tablo 6’ da verilmiştir (Tablo 12).

Tablo 12. Numunelere ait nokta yükü dayanım indeksi değerleri

\begin{tabular}{|c|c|c|c|c|c|c|c|c|c|}
\hline & N.NO & ORT. & $\begin{array}{l}\text { NYD } \\
\text { Mpa }\end{array}$ & $\begin{array}{l}\text { STD } \\
\text { SP. }\end{array}$ & & N.NO & ORT. & $\begin{array}{l}\text { NYD } \\
\text { Mpa }\end{array}$ & $\begin{array}{l}\text { STD } \\
\text { SP. }\end{array}$ \\
\hline \multirow{25}{*}{ 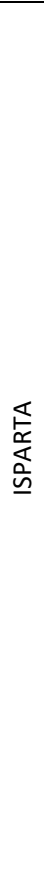 } & Is-1A & 0.69 & \multirow{3}{*}{0.6} & \multirow{3}{*}{0.08} & \multirow{16}{*}{ 夯 } & Af-2 & 3.47 & \multirow{4}{*}{2.27} & \multirow{4}{*}{2.16} \\
\hline & Is-1B & 0.54 & & & & Af-5 & 0.34 & & \\
\hline & Is-1C & 0.58 & & & & Af-10 & 0.55 & & \\
\hline & Is-2A & 0.65 & \multirow{4}{*}{0.9} & \multirow{4}{*}{0.33} & & Af-12 & 4.7 & & \\
\hline & Is-2B & 1.37 & & & & Af-13 & 1.31 & \multirow{2}{*}{1.02} & \multirow{2}{*}{0.4} \\
\hline & Is-2C & 0.86 & & & & Af-14 & 0.74 & & \\
\hline & Is-2D & 0.7 & & & & Af-4 & 0.72 & \multirow{7}{*}{0.48} & \multirow{7}{*}{0.15} \\
\hline & Is-3A & 0.36 & \multirow{10}{*}{0.38} & \multirow{10}{*}{0.38} & & Af- 6 & 0.64 & & \\
\hline & Is-3B & 1.39 & & & & Af-7 & 0.37 & & \\
\hline & Is-3C & 0.57 & & & & Af-8 & 0.51 & & \\
\hline & Is-3D & 0.13 & & & & Af-9 & 0.42 & & \\
\hline & Is-4A & 0.33 & & & & Af-11 & 0.43 & & \\
\hline & Is-4B & 0.24 & & & & Af-15 & 0.3 & & \\
\hline & Is-6A & 0.17 & & & & Af-3 & 0.76 & \multirow{3}{*}{0.58} & \multirow{3}{*}{0.32} \\
\hline & Is-6B & 0.15 & & & & Af-16 & 0.76 & & \\
\hline & Is-6C & 0.27 & & & & Af-17 & 0.21 & & \\
\hline & Is-6D & 0.19 & & & & & & & \\
\hline & Is-4C & 0.47 & \multirow{4}{*}{0.77} & \multirow{4}{*}{0.58} & & & & & \\
\hline & Is-5A & 1.62 & & & & & & & \\
\hline & Is-5B & 0.36 & & & & & & & \\
\hline & Is-5C & 0.61 & & & & & & & \\
\hline & Is-7A & 1.58 & \multirow{4}{*}{1.83} & \multirow{4}{*}{0.27} & & & & & \\
\hline & Is-7B & 1.74 & & & & & & & \\
\hline & Is-7C & 1.77 & & & & & & & \\
\hline & Is-7D & 2.22 & & & & & & & \\
\hline
\end{tabular}




\subsection{Numunelerin spesifik enerji değerleri}

Numunelerin spesifik enerji değerlerine bakıldığında en yüksek değer AF-2 grubuna ait andezitik bazalt numunelerinde gözlenmiştir. En düşük spesifik enerji değeri ise IS-3 kodlu trakit numunelerinde gözlenmiştir. Numunelerin spesifik enerji hesap tabloları Tablo 13,14,15 'de, spesifik enerji değerleri ortalamaları ve standart sapma değerleri Tablo 16’de verilmiştir.

Tablo 13. Numunelere ait spesifik enerji hesap tablosu-1

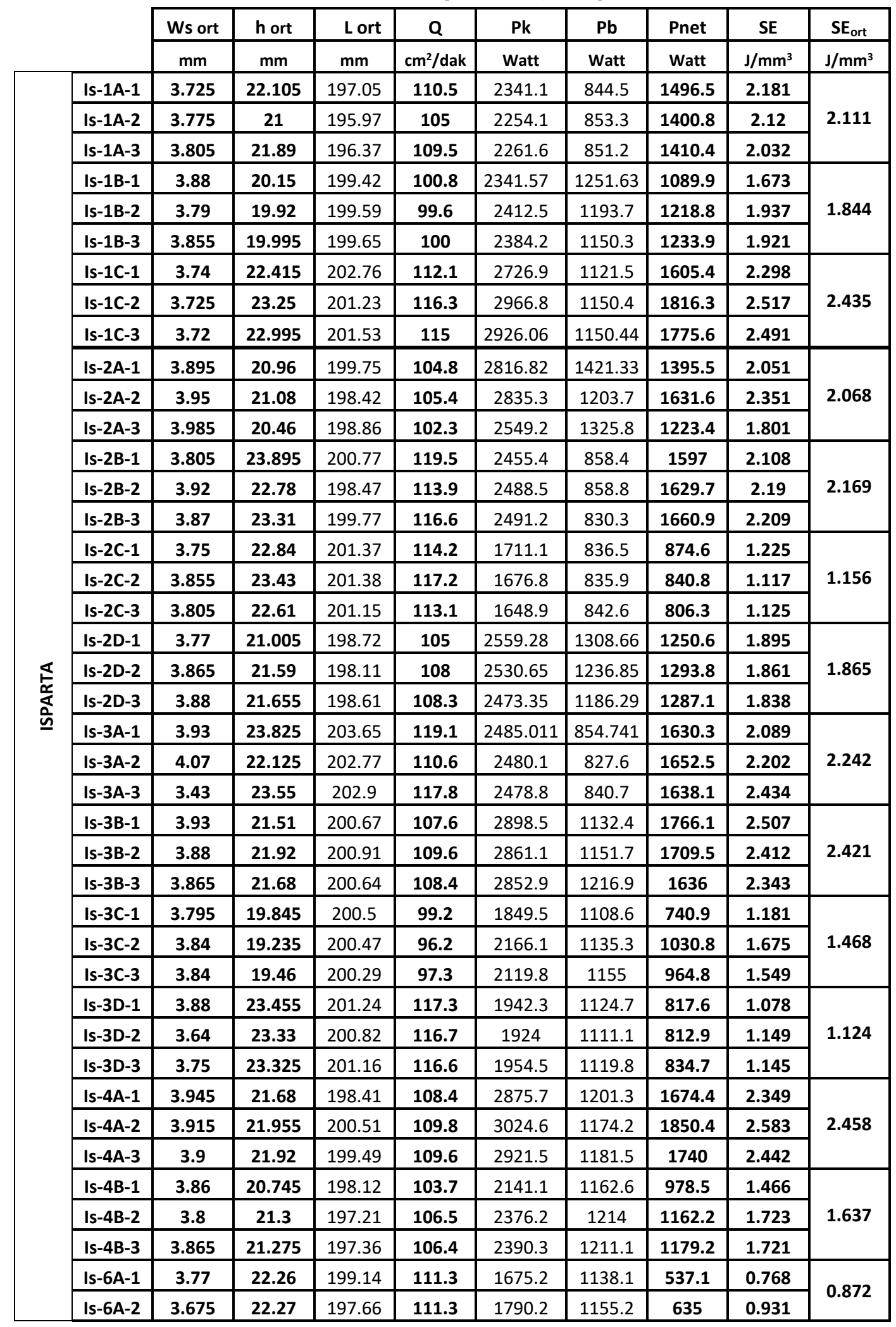


Tablo 14. Numunelere ait spesifik enerji hesap tablosu-2

\begin{tabular}{|c|c|c|c|c|c|c|c|c|c|c|}
\hline & Ws & h & L & $\mathbf{Q}$ & Pk & $\mathrm{Pb}$ & Pnet & SE & SEort \\
\hline & & $\mathrm{mm}$ & $\mathrm{mm}$ & $\mathrm{mm}$ & cm2/dak & Watt & Watt & Watt & $\mathrm{J} / \mathrm{mm} 3$ & $\mathrm{~J} / \mathrm{mm} 3$ \\
\hline \multirow{21}{*}{ 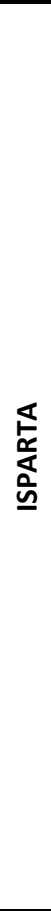 } & Is-6B-1 & 3.745 & 23.88 & 200.04 & 119.4 & 1199.6 & 831.8 & 367.8 & 0.494 & \multirow{3}{*}{0.516} \\
\hline & Is-6B-2 & 3.785 & 24.375 & 199.94 & 121.9 & 1260.6 & 851.3 & 409.3 & 0.532 & \\
\hline & Is-6B-3 & 3.765 & 24.62 & 200.18 & 123.1 & 1259.3 & 855.3 & 404 & 0.523 & \\
\hline & Is-6C-1 & 3.795 & 20.575 & 198.56 & 102.9 & 1890 & 858.2 & 1031.8 & 1.586 & \multirow{3}{*}{1.593} \\
\hline & Is-6C-2 & 3.8 & 21.75 & 199.04 & 108.8 & 1918.4 & 863.6 & 1054.8 & 1.531 & \\
\hline & Is-6C-3 & 3.83 & 20.905 & 198.64 & 104.5 & 2002.1 & 893.5 & 1108.6 & 1.662 & \\
\hline & Is-6D-1 & 3.91 & 22.42 & 197.77 & 112.1 & 1371.7 & 873.5 & 498.2 & 0.682 & \multirow{3}{*}{0.68} \\
\hline & Is-6D-2 & 3.835 & 21.795 & 198.08 & 109 & 1298.8 & 859 & 439.8 & 0.631 & \\
\hline & Is-6D-3 & 3.51 & 22.08 & 197.79 & 110.4 & 1342.4 & 873.2 & 469.2 & 0.726 & \\
\hline & Is-7A-1 & 3.81 & 23.25 & 196.91 & 116.3 & 2524.4 & 822.4 & 1702 & 2.306 & \multirow{3}{*}{2.448} \\
\hline & Is-7A-2 & 3.83 & 22.885 & 196.94 & 114.4 & 2694.5 & 841.5 & 1853 & 2.537 & \\
\hline & Is-7A-3 & 3.77 & 22.875 & 197.14 & 114.4 & 2668.9 & 871 & 1797.9 & 2.502 & \\
\hline & Is-7B-1 & 3.975 & 22.2 & 200.02 & 111 & 2764.8 & 991.3 & 1773.5 & 2.412 & \multirow{3}{*}{2.518} \\
\hline & Is-7B-2 & 3.83 & 21.3 & 199.58 & 106.5 & 2704.1 & 937.7 & 1766.4 & 2.598 & \\
\hline & Is-7B-3 & 3.91 & 22.155 & 199.88 & 110.8 & 2766.4 & 930.6 & 1835.8 & 2.543 & \\
\hline & Is-7C-1 & 3.89 & 21.06 & 197.51 & 105.3 & 2730.3 & 1155.6 & 1574.7 & 2.307 & \multirow{3}{*}{2.341} \\
\hline & Is-7C-2 & 3.87 & 20.875 & 197.67 & 104.4 & 2736.2 & 1149.6 & 1586.6 & 2.357 & \\
\hline & Is-7C-3 & 3.84 & 21.055 & 197.41 & 105.3 & 2729.3 & 1139.3 & 1590 & 2.36 & \\
\hline & Is-7D-1 & 3.885 & 20.805 & 202.42 & 104 & 2785.7 & 1153.3 & 1632.4 & 2.424 & \multirow{3}{*}{2.58} \\
\hline & Is-7D-2 & 3.87 & 20.83 & 204.39 & 104.2 & 2929 & 1169 & 1760 & 2.62 & \\
\hline & Is-7D-3 & 3.89 & 20.75 & 204.04 & 103.8 & 2957.2 & 1142.7 & 1814.5 & 2.698 & \\
\hline \multirow{21}{*}{$\frac{2}{\frac{2}{2}}$} & Af-2-1 & 3.995 & 27.035 & 203.17 & 135.2 & 3027.9 & 859.8 & 2168.1 & 2.409 & \multirow{3}{*}{2.494} \\
\hline & Af-2-2 & 3.965 & 26.275 & 202.71 & 131.4 & 3069.5 & 849.1 & 2220.5 & 2.558 & \\
\hline & Af-2-3 & 4 & 26.515 & 202.6 & 132.6 & 3063.6 & 840.5 & 2223.1 & 2.515 & \\
\hline & Af-5-1 & 3.48 & 21.115 & 199.06 & 105.6 & 1990.958 & 874.087 & 1116.9 & 1.824 & \multirow{3}{*}{1.629} \\
\hline & Af-5-2 & 3.8 & 20.69 & 199.76 & 103.5 & 1852.317 & 892.2581 & 960.1 & 1.465 & \\
\hline & Af-5-3 & 3.75 & 20.65 & 199.39 & 103.3 & 1927.296 & 896.25 & 1031 & 1.598 & \\
\hline & Af-10-1 & 3.9 & 20.95 & 200.4 & 104.8 & 2192.659 & 1154.031 & 1038.6 & 1.525 & \multirow{3}{*}{1.4} \\
\hline & Af-10-2 & 3.9 & 21.04 & 202.42 & 105.2 & 2061.385 & 1146.632 & 914.8 & 1.338 & \\
\hline & Af-10-3 & 3.9 & 21.305 & 201.51 & 106.5 & 2059.098 & 1132.5 & 926.6 & 1.338 & \\
\hline & Af-12-1 & 3.985 & 18.57 & 146.1 & 92.9 & 3957.929 & 1126.102 & 2831.8 & 4.592 & \multirow{3}{*}{4.394} \\
\hline & Af-12-2 & 3.965 & 19.085 & 165.93 & 95.4 & 3845.889 & 1128.863 & 2717 & 4.309 & \\
\hline & Af-12-3 & 4 & 18.765 & 149.43 & 93.8 & 3828.913 & 1150.776 & 2678.1 & 4.282 & \\
\hline & Af-3-1 & 3.705 & 21.23 & 201.58 & 106.2 & 2964 & 1146.19 & 1817.8 & 2.773 & \multirow{3}{*}{2.805} \\
\hline & Af-3-2 & 3.115 & 21.42 & 201.76 & 107.1 & 2855.961 & 1172.455 & 1683.5 & 3.028 & \\
\hline & Af-3-3 & 3.92 & 21.295 & 201.96 & 106.5 & 3001.261 & 1183.406 & 1817.9 & 2.613 & \\
\hline & Af-16-1 & 3.875 & 22.025 & 201.66 & 110.1 & 2811.556 & 1135 & 1676.6 & 2.357 & \multirow{3}{*}{2.492} \\
\hline & Af-16-2 & 3.895 & 21.56 & 201.65 & 107.8 & 2971.735 & 1142.413 & 1829.3 & 2.614 & \\
\hline & Af-16-3 & 3.935 & 21.575 & 201.68 & 107.9 & 2911.403 & 1138.529 & 1772.9 & 2.506 & \\
\hline & Af-17-1 & 3.69 & 23.495 & 200.67 & 117.5 & 1933.946 & 891.8919 & 1042.1 & 1.442 & \multirow{3}{*}{1.519} \\
\hline & Af-17-2 & 3.765 & 23.065 & 196.39 & 115.3 & 2020.6 & 884.2632 & 1136.3 & 1.57 & \\
\hline & Af-17-3 & 3.695 & 23.235 & 201.7 & 116.2 & 1982.432 & 876.7612 & 1105.7 & 1.545 & \\
\hline
\end{tabular}


Tablo 15. Numunelere ait spesifik enerji hesap tablosu-3

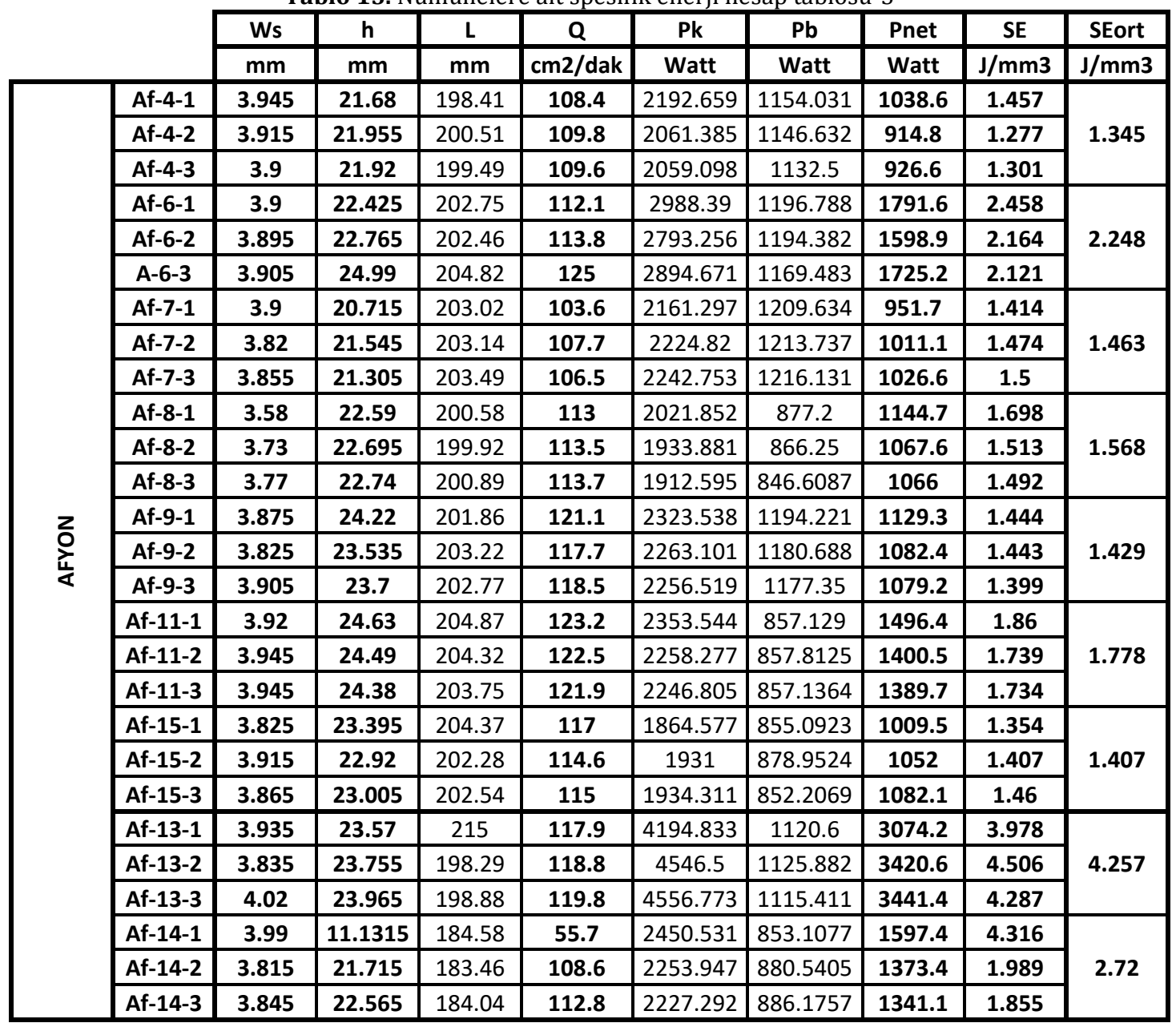

Tablo 16. Numune gruplarına ait spesifik enerji ve standart sapma değerleri

\begin{tabular}{|c|c|c|c|c|c|c|c|c|c|}
\hline & N.NO & $\begin{array}{c}\text { SE } \\
\mathrm{J} / \mathrm{mm}^{3}\end{array}$ & $\begin{array}{c}\text { SE } \\
\text { ORT. }\end{array}$ & $\begin{array}{l}\text { STD } \\
\text { SP. }\end{array}$ & & N.NO & $\begin{array}{c}\text { SE } \\
\mathrm{J} / \mathrm{mm}^{3}\end{array}$ & $\begin{array}{c}\text { SE } \\
\text { ORT. }\end{array}$ & $\begin{array}{l}\text { STD } \\
\text { SP. }\end{array}$ \\
\hline \multirow{25}{*}{ 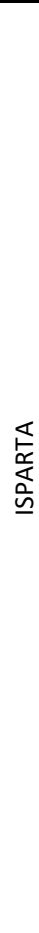 } & Is-1A & 2.11 & \multirow{3}{*}{2.13} & \multirow{3}{*}{0.3} & \multirow{16}{*}{$\begin{array}{l}z \\
\frac{2}{4} \\
\frac{1}{4}\end{array}$} & \multirow{3}{*}{$\begin{array}{l}\text { Af-2 } \\
\text { Af-5 } \\
\text { Af-10 }\end{array}$} & \multirow{2}{*}{$\begin{array}{l}2.49 \\
1.63\end{array}$} & \multirow{4}{*}{2.48} & \multirow{4}{*}{1.36} \\
\hline & Is-1B & 1.84 & & & & & & & \\
\hline & Is-1C & 2.44 & & & & & 1.40 & & \\
\hline & Is-2A & 2.07 & \multirow{4}{*}{1.82} & \multirow{4}{*}{0.46} & & Af-12 & 4.39 & & \\
\hline & Is-2B & 2.17 & & & & Af-13 & 4.26 & 310 & 1 . 0 \\
\hline & Is-2C & 1.16 & & & & Af-14 & 2.72 & 0.40 & כ. \\
\hline & Is-2D & 1.86 & & & & Af-4 & 1.34 & & \\
\hline & Is-3A & 2.24 & & & & Af-6 & 2.25 & & \\
\hline & Is-3B & 2.42 & & & & Af-7 & 1.46 & & \\
\hline & Is-3C & 1.47 & & & & Af-8 & 1.57 & 1.61 & 0.32 \\
\hline & Is-3D & 1.12 & & & & Af-9 & 1.43 & & \\
\hline & Is-4A & 2.46 & 150 & 71 & & Af-11 & 1.78 & & \\
\hline & Is-4B & 1.64 & 1.00 & 0.71 & & Af-15 & 1.41 & & \\
\hline & Is-6A & 0.87 & & & & Af-3 & 2.81 & & \\
\hline & Is-6B & 0.52 & & & & Af-16 & 2.49 & 2.27 & 0.67 \\
\hline & Is-6C & 1.59 & & & & Af-17 & 1.52 & & \\
\hline & Is-6D & 0.68 & & & & & & & \\
\hline & Is-4C & 2.54 & & & & & & & \\
\hline & Is-5A & 1.84 & 200 & 1 22 & & & & & \\
\hline & Is-5B & 1.86 & 2.00 & כבנ. & & & & & \\
\hline & Is-5C & 1.98 & & & & & & & \\
\hline & Is-7A & 2.52 & & & & & & & \\
\hline & Is-7B & 2.34 & 251 & 011 & & & & & \\
\hline & Is-7C & 2.58 & 2.00 & 0.11 & & & & & \\
\hline & Is-7D & 2.58 & & & & & & & \\
\hline
\end{tabular}




\section{Verilerin değerlendirilmesi}

Şekil 4' de görüldüğü gibi numunelerin doku katsayısı ile spesifik enerjileri arasında $\mathrm{r}=0.56$ katsayılı bir ilișki gözlemlenmiştir.

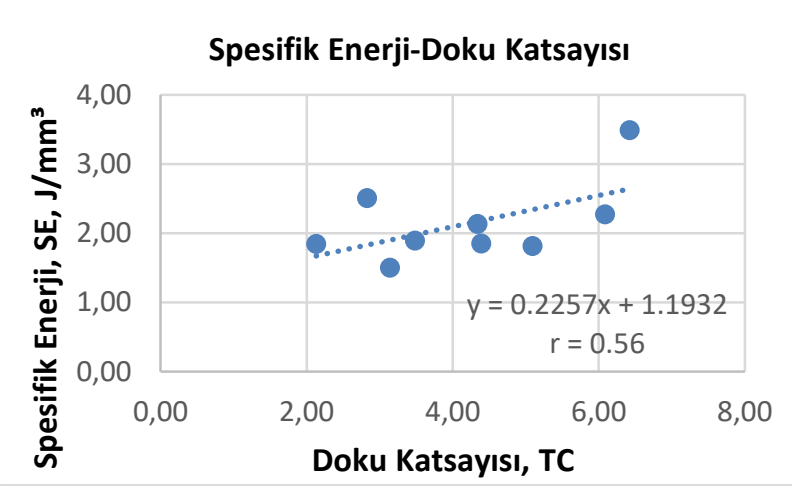

Şekil 4. Kayaç gruplarına ait spesifik enerji ortalamaları ile doku katsayısı ortalamaları arasındaki ilişki

IS-1 grubu ve AF-4 grubu içerisindeki kayaçlar ele alındığında en yüksek doku katsayısı değerleri (Tablo 6) mikrolitik porfirik dokulu Af-3 ve Af-17 numunelerinde gözlenmiştir (Şekil 5). $\mathrm{Bu}$ doku fenokristal olarak bulunan minerallerin küçük, ince taneli bir formda gene fenokristallerin etrafını çevirdiği bir matriks veya hamurdan meydana gelir. Mikrolitik tanelerin matriks içinde birbirleriyle olan yakınlıkları ise doku katsayısını yükseltmektedir.

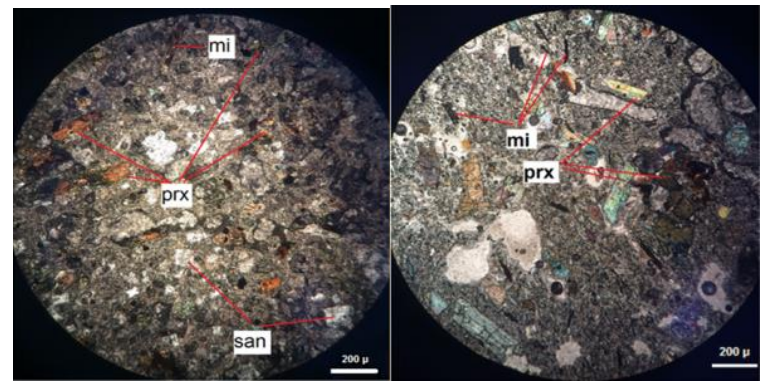

Şekil 5. Af-3 ve Af-17 numunelerine ait incekesit görüntüsü

IS-2 grubunda bulunan kumtaşlarında doku katsayısı ve buna bağlı spesifik enerji kullanımı farklılık göstermektedir. Mineralojik olarak ele alındığında detritik dokulu olan Is-2A ve Is-2D numunelerinin yüksek çıkan doku katsayılarının (Tablo 6) sebebi tanelerin yuvarlaklıklarının yüksek olması ve fenokristaller arasını küçük çaptaki mineral tanelerinin sıkı bir bağlamla bulunmasıdır (Şekil 6). Bu da kayaç dayanımını yükseltmektedir.

IS-3 grubu ele alındığında gruba ait numuneler arasında mineralleri büyük, köşeli ve geometrik şekilli fenokristallerin yoğun olarak bulunduğu Is-3B, Is-3C, Is-4A ve Is-4B kodlu trakit numunelerinde (Şekil 7) doku katsayılarının yüksek olduğu gözlenmiștir (Tablo 6).

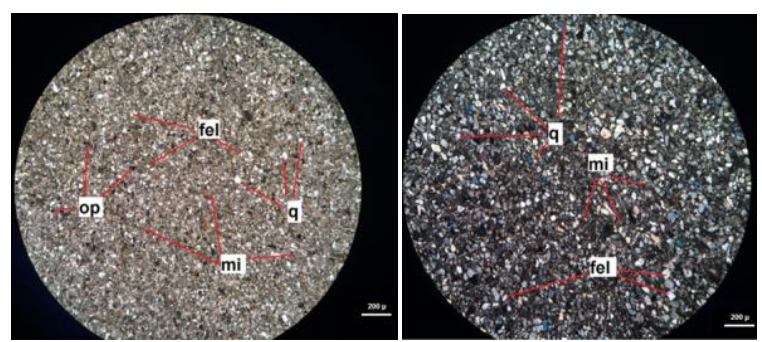

Şekil 6. Is-2A ve Is-2D numunelerine ait incekesit görüntüsü

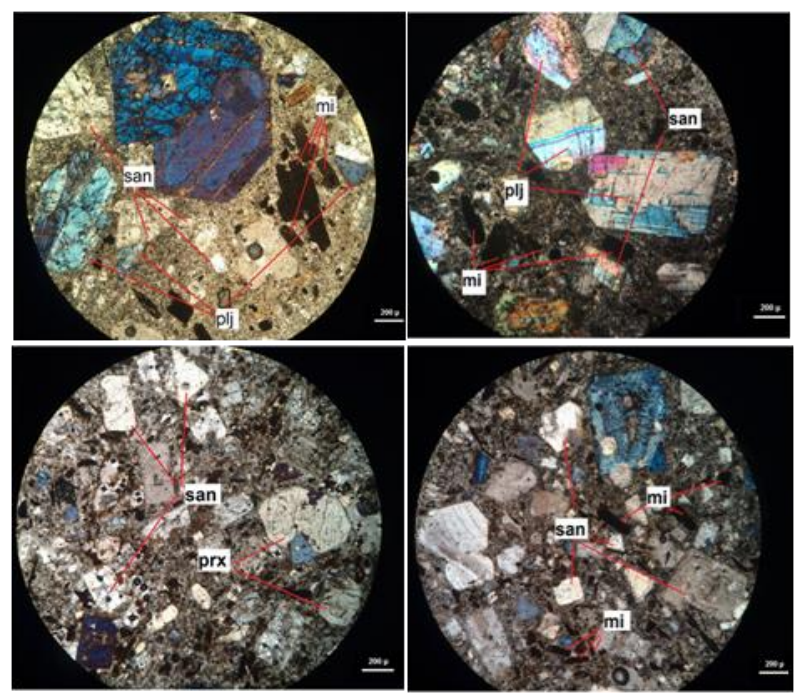

Sekil 7. Is-3B, Is-3C, Is-4A ve Is-4B numunelerine ait incekesit görüntüleri

IS-4 ve AF-3 grubunu oluşturan bazaltik trakiandezit numunelerinde çeşitli doku tipleri gözlenmiştir (Tablo2,3). Ancak bu iki gruba ait tüm numunelerde kayaç hamurunu oluşturan mikrolitik mineraller yoğun olarak gözlenmiștir(Şekil 8). İki grupta da doku katsayısı yüksek olan (Tablo 6) Is-4C, Af-6, Af-8 ve Af-11 kodlu numunelerde (tıpkı IS-3 grubunda olduğu gibi) büyük ve köşeli mineraller gözlenmiştir (Şekil 8). Bu mineraller arasını dolduran mikrolitik yapıdaki taneler arası sıkı bir matriks söz konusudur.

IS-5 grubuna ait fonolitler de farklı doku katsayları elde edilmiştir. $\mathrm{Bu}$ gruba ait tüm numuneler intergranüler doku tipine sahiptir. İntergranüler doku kayaçlar içerisinde fenokristal olarak minerallerin aralarını sık bir bağlamla plajioklas minerallerinin doldurmasıyla meydana gelir. Ancak IS-5 grubunda en yüksek doku katsayısına (Tablo 6) sahip olan Is-7A ve Is-7B numuneleri mineralojik olarak ele alındığında diğer numunelere göre fenokristalleri arası tamamen plajioklas mineraliyle dolmuştur (Şekil 9). Yani bu iki numuneye ait fenokristaller arasında neredeyse hiç boşluk olmamakla birlikte taneler arası tamamen plajioklas minerali ile dolu olup plajioklaslarla fenokristaller bütünüyle sınır ilișkisi içerisindedir. Bu da kayacın dayanımını yükseltmektedir. 


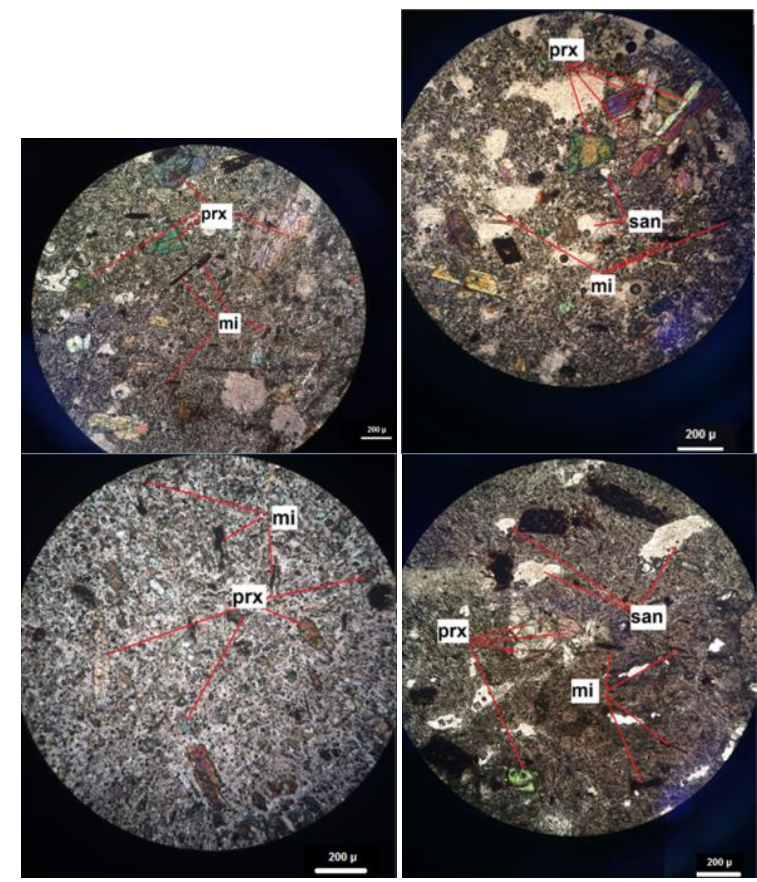

Şekil 8. Is-4C, Af-6, Af-8 ve Af-11 numunelerine ait incekesit görüntüleri
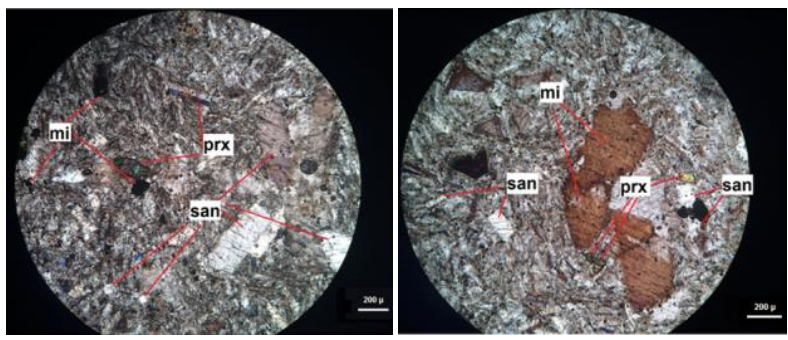

Şekil 9. Is-7A ve Is-7B numunelerine ait incekesit görüntüleri

Son grup olan AF-1 grubunu oluşturan lösititler porfirik dokulu kayaçlardır. Doku katsayısı ele alındığında Af-12 numunesi diğer lösitit numunelerine göre daha yüksek çıkmıştır (Tablo 6). Bunun sebebi diğer numunelere oranla bu numunede mineral tane boyları daha büyüktür (Șekil 10). Büyük formda olan bu fenokristaller arasında önemli ölçüde sınır ilişkisi gözlenmektedir (Şekil 10). Bu durumda kayacın bağlamı yüksek olmakla birlikte dayanımı artmıștır.

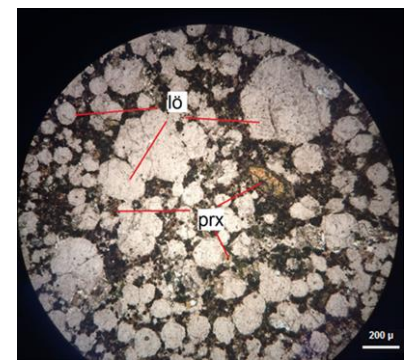

Şekil 10. Af-12 numunesine ait incekesit görüntüsü

Numunelerin spesifik enerjileri ve tanelere ait șekil faktörü arasındaki ilișki araștırılırken bașta anlamlı bir ilișki elde edilemezken sapan değerlere sahip olan AF-4 ve AF-3 kodlu numune gruplarına ait değerler çıkartıldığında Şekil 11 'de görüldüğü üzere numunelerin spesifik enerji ve şekil faktörü değerleri ortalamalarının kullanıldığı grafikte tanelere ait şekiller ile kesilebilirlikleri arasında anlamlı bir ilişki vardır .

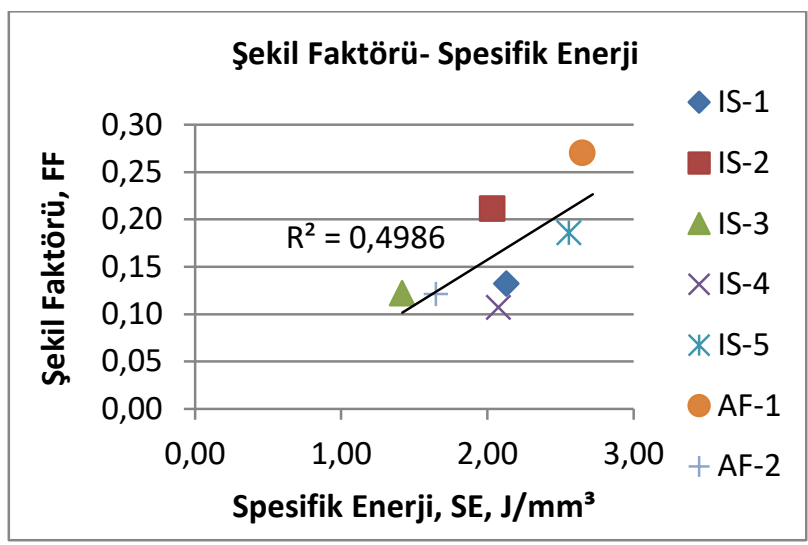

Şekil 11. Kayaç gruplarına ait spesifik enerji ortalamaları ile şekil faktörü değerlerinin ortalamaları arasındaki ilişki

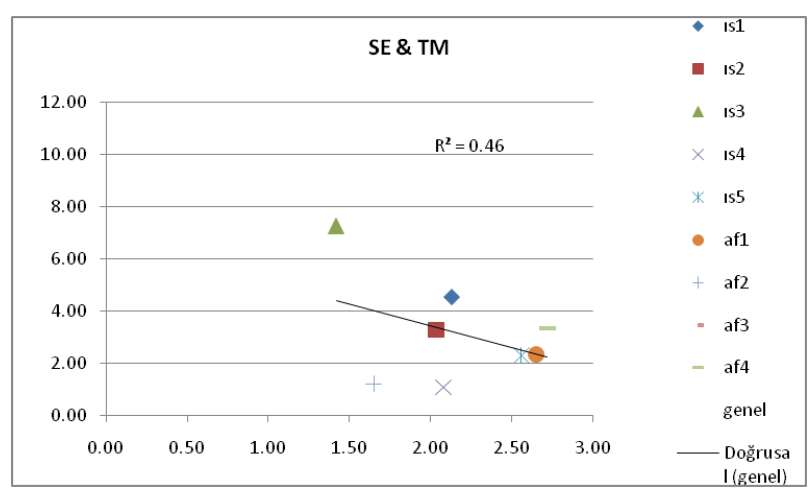

Şekil 12. Kayaç gruplarına ait spesifik enerji ve numunelerin içerisindeki tanelerin alanlarının toplamın matrikse oranı değerlerinin ilişkisi

Tanelerin șekillerinin ve büyüklüklerinin, kayaç içerisindeki kapladıkları alanın ve bulunma oranlarının spesifik enerjiyi ne kadar etkilediğini belirleyebilmek amacıyla yapılan grafik Şekil 12 'de verilmiştir. Bașta düşük bir katsayı elde edilen ilișkide AF-2 kodlu numune grubuna ait değerler çıkartıldığında $\mathrm{R}^{2}=0.46$ katsayılı bir ilişki elde edilmiştir. $\mathrm{Bu}$ durumda mineral tanelerinin kayaç içerisindeki bulunma oranları, matriks içerisindeki mineral tanelerinin kapladığı alanın ve tane büyüklüklerinin kayacın dayanımını etkilediği aynı zamanda spesifik enerji kullanımını arttırdığı sonucuna varılmıștır.

Lösitit numunelerinin olușturduğu AF-1 kodlu grupta en yüksek sismik hız (Tablo 8) ve nokta yükü dayanım indeksi (Tablo 12) değerinin çıkması lösitit kayacını oluşturan tanelerin hem büyük boyutta ve yuvarlaklığının yüksek olması hem de kayaç içerisinde kırık, çatlak ve gözenekliliğin diğer kayaç numunelerine oranla daha az olmasıdır.

Schmitd çekiç sertliği değerlerine bakıldığında IS-4 kodlu bazaltik trakiandezit numuneleri ve IS-5 kodlu fonolit numunelerinde yüksek çıkmıștır (Tablo 9). 
Nedeni büyük, çok büyük, öz şekilli, yarı özşekilli tanelerin bulunma oranının diğer kayaçlara göre fazla olmasıdır.

Kütlece su emme (Tablo 10) ve görünür porozite (Tablo 11) değerleri en yüksek çıkan grup IS-3 kodlu trakit numunelerinin oluşturduğu gruptur. Kütlece su emme ve görünür porozite değerlerinin yüksek çıkması trakit kayacına ait numunelerin içerisinde mevcut olan gözeneklerin tamamına yakınının suyla dolduğunu yani numuneler içerisinde volkanik kayaçlarda sıkça gözlenen gaz boșluklarının fazla olmasından dolayıdır. Aynı zamanda bu durum kayaca ait birim hacim ağırlık (Tablo 7) ve spesifik enerji (Tablo 16) değerinin düşük çıkmasına yani kayacın kesilebilirliğinin kolaylaşmasını sağlamaktadır.

\section{Tartışma ve Sonuç}

Genel olarak tüm çalıșma ele alındığında en düșük doku katsayılarına (TC) sahip olan lösitit numuneleri kumtaşlarına oranla daha yüksek yuvarlaklık katsayısına (FF) sahiptir. Ancak lösitit kayaçlarında spesifik enerji değeri (SE) kumtaşına oranla daha yüksek olarak bulunmuştur (Tablo 16). Bu durumda tane yuvarlaklık katsayısı kayaç dayanımını etkilediği açıktır. Bunun yanı sıra litaretür de geçen tane yuvarlaklığının öneminin yanında kayaçlar içerisinde bulunan fenokristallerin öz şekilli, yarı özşekilli, geometrik şekilli ve tane büyüklükleri de doku katsayılarını ciddi derecede etkilemektedir. Buna bağlı olarak kayaç dayanımlarının da artmasıyla spesifik enerji kullanımı artmaktadır.

Kayaçlara ait doku tipleri ele alındığında ise taneler arasını dolduran hamur veya matriks içerisinde mikrolitik yapıdaki minerallerin yoğunluğu ve tüm taneler arası sınır ilişkisi arttıkça doku katsayısı yükselmekte ve kayaç dayanımı artmaktadır.

Sonuç olarak kayaç dayanımının sayısallaştırılabileceği, tane yuvarlaklığının önemli olduğu, mineral tane büyüklüğünün, fenokristallerin geometrik şekillerinin, hamur veya matriksin içerisinde bulunan mikrolitik yapıdaki minerallerin yoğunluğunun ve mineral taneleri arası temasın arttıkça kayaç dayanımının yükseldiği gözlenmiştir. Bunların yansıra spesifik enerji ile doku katsayısı arasında doğru orantılı anlamlı bir ilişki elde edilmiş olup dairesel testerelerin kullanımında doku katsayısı parametresinin kullanılabilirliği hem zaman kazancını hem de kesime ait verimi arttırabileceği anlaşılmıştır.

\section{Kaynakça}

[1] Şengün, N. 2009. Kayaçların Kırılma Tokluğu ve Gevrekliğinin Dairesel Testereler ile Kesme Verimi Üzerine Etkileri. Süleyman Demirel Üniversitesi, Fen Bilimleri Enstitüsü, Doktora Tezi, 180s, Isparta.

[2] Şengün N., Altindağ R., Erinç Koçcaz C., "Isparta Yöresinde Bulunan Bazı Mağmatik Kökenli Kayaçların Kesilebilirlik Analizi", DEÜ Fen ve Mühendislik Dergisi, cilt.11, ss.22-31, 2009.

[3] Öztürk, C.A. 2006. Kayaç dokusal özelliklerinin sinıflandırılması ve kaya mühendisliği uygulamaları. İstanbul Teknik Üniversitesi, Fen Bilimleri Enstitüsü, Yüksek Lisans Tezi, 220s, İstanbul.

[4] Howarth, D.F., Rowlands, J.C. 1987. Quantitative Assessment of Rock Texture And Correlation With Drillability And Strength Properties. Rock Mechanics and Rock Engineering, 20(1987), 5785, England.

[5] Öztürk, C. A., Nasuf, E., ve Bilgin, N., 2004. The Assessment of Rock Cuttability and Physical and Mechanical Rock Properties From a Texture Coefficient, J. South African Ins. Mining and Metallurgy, 7, 397-403.

[6] Tiryaki, B. vd., 2003. Kayaç Kesmede Keski Performansının Tahmini İçin Doku Katsayısı Yaklaşımının Kullanılabilirliği, Madencilik Dergisi, Cilt 42, Sayı 2, Syf 27-43.

[7] Günaydın, S. 2006. Kayaçların doku katsayıları ile fiziko-mekanik özellikleri arasındaki ilişkilerin incelenmesi. Süleyman Demirel Üniversitesi, Fen Bilimleri Enstitüsü, Yüksek Lisans Tezi, 80s, Isparta.

[8] TS EN 1936, 2010. Doğal taşlar - Deney yöntemleri - Gerçek yoğunluk, görünür yoğunluk, toplam ve açık gözeneklilik tayini, TSE, Ankara.

[9] TS EN 13755, 2009. Doğal taşlar-Deney metotları-Atmosfer basıncinda su emme tayini, TSE,Ankara.

[10] TS EN 14579, 2006. Doğal taşlar - Deney yöntemleri-Ses hızı ilerlemesinin tayini, TSE, Ankara.

[11] ISRM 1981, Rock Characterization, Testing and Monitoring -ISRM Suggested Methods, Pergamon Press", Oxford, Brown, E.T. (ed), 211 p. 